\title{
Environmental assessment of a nano-technological aerogel-based panel for building insulation
}

\author{
Aitana Saez de Guinoa ${ }^{\mathrm{a}}$, David Zambrana-Vasquez ${ }^{\mathrm{a}}$, Alfonso Alcalde ${ }^{\mathrm{a}}$, Marco Corradini ${ }^{\mathrm{b}}$, \\ Ignacio Zabalza-Bribián ${ }^{*}$ \\ ${ }^{a}$ Research Centre for Energy Resources and Consumption (CIRCE), CIRCE Building - \\ Campus Río Ebro, Mariano Esquillor Gómez, 15, 50018, Zaragoza, Spain \\ bAMA COMPOSITES srl- Via Repubblica, 7, 41011, Campogalliano (MO), Italy \\ ${ }^{c}$ Research Centre for Energy Resources and Consumption (CIRCE) - University of Zaragoza, \\ CIRCE Building - Campus Río Ebro, Mariano Esquillor Gómez, 15, 50018 Zaragoza, Spain
}

\begin{abstract}
This study assesses the life-cycle environmental implications linked to the energy efficiency improvement by a nano-technological aerogel based panel insulation solution. A cradle to grave approach has been taken for the environmental evaluation of the product life-cycle, including its integration in an existing residential building for the evaluation of the building's use phase. The model developed has been also assessed in the 5 European climate zones, evaluating the different performance due to the different weather conditions and the effect of increasing the thickness used. Also, an evaluation of the impacts achieved depending on the heating source used, together with the comparative analysis with other traditional insulation materials complete the paper.
\end{abstract}

This innovative aerogel based panel takes advantage of nanotechnology to increase its lifetime and reduce its thickness, in-building installation time and cost in comparison to conventional insulating materials. As a result, due to its low thermal conductivity $(0.015$ $\mathrm{W} / \mathrm{mK}$ ), only $10 \mathrm{~mm}$ aerogel based insulation panel is needed to achieve the same level of insulation of $25 \mathrm{~mm}$ thickness of standard Expanded Polystyrene Panel. This difference increases when the passive house requirements of façade thermal insulation are considered with thermal transmittance values in the range between 0.1 to $0.15 \mathrm{~W} /\left(\mathrm{m}^{2} \mathrm{~K}\right)$. From the results, a reasonable thickness of insulation material is available only with Aeropan in comparison to Expanded Polystyrene, Extruded Polystyrene and Mineral Wool, demonstrating its suitability in the accomplishment of passive house requirements with a significant reduction of the space needed.

Thus, net life-cycle environmental benefits were found in all scenarios making this product suitable for the retrofitting of existing buildings by both, external or internal thermal insulation, minimizing at the same time the space occupied by the insulation solution.

\section{KEYWORDS}

Life cycle assessment, building insulation, nanotechnology, energy efficiency, building retrofitting, passive house. 
NOMENCLATURE

\section{Acronyms}

CED - Cumulative Energy Demand

CTE - Technical Building Code

ELCD - European Life Cycle Database

EPD - Environmental Product Declaration

EPS - Expanded Polystyrene

EHI - European Heating Index

GW - Glass Wool

HDD - Heating Degree-Days

LCA - Life Cycle Assessment

LCI - Life Cycle Inventory

LWRT - Lightweight Reinforced Thermoplastic

PU - Polyurethane

SW - Stone Wool

XPS - Extruded Polystyrene 


\section{INTRODUCTION}

According to the European Commission's Energy-efficient Buildings partnership, the building sector represents about $40 \%$ of total final energy consumption and contributes about $36 \%$ to the European greenhouse gases emissions (European Commission, 2013). In addition, this sector is responsible for about half of the $\mathrm{CO}_{2}$ emissions not covered by the Emission Trading System (Commission of the European Communities (COTEC), 2008). On the other hand, it is also noteworthy that the building sector represents the area with the greatest potential for intervention (Proietti et al., 2013). Given this key role, the European regulatory framework about energy efficiency in buildings, Energy Performance of Buildings Directive 2010/31/EU (European Commission, 2010) and the Energy Efficiency Directive 2012/27/EU (European Union, 2012), stablishes a binding package of energy efficiency measures for both new and existing buildings, that must be implemented by Member States. This package is set up to meet the EU's 2020 target towards nearly zero-energy new buildings and the improvement of the energy efficiency of existing buildings.

As a result of this regulatory framework, higher requirements for thermal insulation have been already implemented in the national regulations for new and existing buildings. At Spanish level, the section 1 of the Basic Document of Saving of energy (DB-HE), from the Technical Building Code (CTE) (CTE DB-HE, 2013), sets different limits for the energy demand of buildings depending on the climatic zone of the building's location and its use. Thus, the characteristics of the thermal envelope's elements must meet these constraints preserving the thermal quality of living spaces. Nevertheless, at EU level, the renovation rate of existing buildings is stills at a very low level (1-1.5\% per year), and taking into consideration that about $35 \%$ of the European building stock is over 50 years old, several strategies for improvement at national level are needed (European Commission, 2013). Furthermore, the

current renovation rate will need to be doubled, mainly among continental northern 
hemisphere countries where it is expected that $75 \%-90 \%$ of current building stock will be existing in 2050 (International Energy, 2013).

Thermal insulation improvement in buildings plays a key role in decreasing the energy demand in the residential sector, since space heating is the most important end-use, $(60-80 \%$ of total energy consumption, excluding Mediterranean countries), enhancing users' thermal comfort at the same time (Pardo et al., 2012). From an experimental study, an energy reduction up to $37 \%$ in winter can be reached with the inclusion of thermal insulation in the building's envelope at Mediterranean level (Cabeza et al., 2010). Several different thermal insulation panels are present on the market that differ in the type of insulation material used or intended by the manufacturer and/or applicator e.g. Expanded Polystyrene (EPS), Extruded Polystyrene (XPS), Polyurethane (PU), Stone Wool (SW), Glass wool (GW) and wood fiber. Considering the worldwide market, the most common materials representing the $90 \%$ are SW, GW, EPS, XPS and PU (Sierra-Pérez et al., 2016). At European level, the market of insulating materials is dominated of two groups of products i) inorganic fibrous materials such as GW and SW, accounting approximately for $60 \%$ of the market, and ii) organic foamy materials like EPS, XP, PU, this last with a lesser extent, accounts for approximately $27 \%$ of the market, being that the rest of other insulation materials accounted for less than $13 \%$ together (Papadopoulos, 2005). From the same source, considering the European producers, there are approximately 250 companies, where nine of them accounted for more than $55 \%$ of the total annual production in 2003. A more recent classification of thermal insulation materials is proposed by (Jelle, 2011) as: i) traditional thermal building insulation (Mineral wool, EPS, XPS, cellulose, cork and PU); ii) the available thermal building insulations with the actual lowest thermal conductivity (Vacuum insulation panels, gas-filled panels, aerogels and phase change materials); and iii) possible future thermal building insulation (Vacuum insulation materials, Gas insulation materials, nano-insulation materials, dynamic insulation 
materials, concrete and applications of NIMs and NanoCon). In addition, (Asdrubali et al., 2015) made a review of unconventional building insulation materials, presenting a classification and description of two groups of materials: i) Natural and ii) Recycled materials. One of the main conclusions from this review is that even some unconventional material's properties should be investigated and improved, notable economic and environmental benefits can be obtained due to the use of local resources.

Several studies have focused on the impact of insulating materials regarding energy efficiency and environmental impact balance (considering manufacturing impacts) using Life Cycle Assessment (LCA) approaches, which is increasing international acceptance in the building sector. On the one hand, Zabalza Bribián et al., 2009 and Zabalza Bribián et al., 2011 compiled more than 35 studies highlighting the relevance of the LCA to analyse and reduce the environmental impact of the building materials and the existing residential buildings (Zabalza Bribián et al., 2009; Zabalza Bribián et al., 2011). Also, Pombo et al., 2016 analysed the existing limitations of the LCA, its application to the optimal retrofitting solution finding and the identification of the improvement potential of building renovation (Pombo et al., 2016). After the study of the application of the European Standards related to the sustainability of construction works to improve the LCA methodology application at end-of life stage, Silvestre et al., 2014 highlighted that it should be included the detailed analysis of the reuse, recovery and/or recycling potential in order to develop a 'cradle to cradle' approach of construction materials, e.g. building insulation materials (Silvestre et al., 2014). In addition, Sohn et al., 2017, analysed the trade-off in terms of environmental impacts, from a building's LCA approach, between the heat produced for building's space heating load and insulation produced to reduce it, considering manufacturing impacts (Sohn et al., 2017). Finally, Su et al., 2016, developed a comparison of the life cycle performance of eight insulations materials through a Monte-Carlo based uncertainty analysis determining that there 
is no relevant difference in the life cycle primary energy among PU, EPS and XPS (Su et al., 2016). Some of these studies, also indicated that research about advanced insulating materials is needed, e.g. innovative mineral fiber insulating panels (Moretti et al., 2016) and aerogel, showing this last a great potential for improving the thermal insulation of historic buildings (Walker and Pavía, 2015) . Additionally, some other state of the art review studies of both traditional and solutions beyond these building insulation materials (Jelle, 2011) e.g. Aerogel insulation for building applications (Baetens et al., 2011), concluded that, in comparison to the conventional insulations materials, nanotechnology based materials could be a promising solution in the nearby future in terms of indoor thermal comfort conditions, embodied energy, thermal bridging issues and slimmer construction (Hostler et al., 2009). By contrast, conventional insulations have small gap for improvement and leads to complex, heavy and thick construction solutions when willing to achieve better thermal transmittance (U-value) (Cuce et al., 2014b). Thus, in comparison to conventional insulation materials, aerogel-based thermal insulation affords slimmer constructions in buildings (Cuce et al., 2014a). Aerogel is considered as super insulation material $(0.015 \mathrm{~W} / \mathrm{mK})$ due to its open-cell nano-porous structure, which results from a sol-gel process and supercritical drying process. The major disadvantage of aerogel for its use as insulation material is its fragility; therefore its composite with other materials with higher toughness is needed (Wei et al., 2011), such as Aeropan panel (Casini, 2016). The specific solution assessed in this paper consist of an Aerogel reinforced with glass fibre blanket and coupled to a breathable membrane made of polypropylene, which make up a self-sustaining insulating panel. In relation to potential human health impacts, Cuce et al. (2014a) also studied the possible health problems by aerogels. They remark the reduction of possible health risks at exposure of the aerogel consisted of amorphous silica instead of crystalline silica. Additionally, they include a set of recommendations to avoid health problems mainly during installation caused by aerogels. In 
this sense, given the growing interest in aerogel based thermal insulations materials for the construction sector, besides the study of their thermal properties, the improvement of rigidity and dust minimization; it is also necessary to evaluate their environmental implications and their integration in different case studies from a cradle to grave approach (with the inclusion of the construction, use and end-of life phases). In addition, reviewed studies exposes that many development opportunities exist since long life thin insulated panels with high performances are still missing on the market and "adapted" products for external thermal insulation which keep the aesthetic aspect of a building and which are easy to install are strongly requested. It is estimated that the total market for thermal insulation products in Europe stood at just under 234.6 million $\mathrm{m}^{3}$ in 2014 (7.4 million tonnes). This equates to an approximate market value of $€ 11.5$ billion. Commercial and domestic buildings continue to represent the bulk of the demand for thermal insulation materials in Europe, with the overall use in industrial applications remaining smaller. The percentage of market penetration of aerogel-based insulation materials is still negligible due to the novelty of the products (IAL Consultants, 2015).

This study assesses the environmental performance linked to the energy efficiency improvement of a nano-technological aerogel-based panel insulation solution (hereafter Aeropan) developed in the AEROPAN project $^{1}$ from the EU Eco-innovation programme. Aeropan takes advantage of nano-technology by reducing the thickness needed due to its low thermal conductivity $(0.015 \mathrm{~W} / \mathrm{mK})$, resulting in a significant reduction of the space needed

\footnotetext{
${ }^{1}$ www.aeropan-project.eu
} 
by the insulating solution, especially when very low thermal transmittance values, in the range between $0.1-0.15 \mathrm{~W} / \mathrm{m}^{2} \mathrm{~K}$ according the passive house requirements ${ }^{2}$, are considered.

The environmental impacts have been considered throughout the life-cycle of the related activities: from extraction of raw materials to production, distribution, use and final disposal or recycling on a full life-cycle approach. Thus, two approaches are considered in the assessment developed in this paper: firstly, an holistic approach considering all stages of the product life-cycle (cradle to gate approach); and secondly a case study to assess its integration in a representative dwelling in a residential block of buildings retrofitting, quantifying the net environmental benefits related to the reduction of the energy demand during the use phase of the building and considering the end-of-life phase (cradle to grave approach). In contrast to a single evaluation of the product/process itself, this last approach allows for the consideration of up-stream and down-stream processes as well. In addition, a sensitivity analysis considering the 5 European climate zones proposed by (Hermelink et al., 2013) has been included in the paper with the aim of evaluating the Aeropan performance in terms of environmental impact and energy savings, under different weather conditions. Also, the effect of using higher Aeropan's thickness in the different climate zones has been assessed, in terms of energy demand reduction and considering the different national regulations in respect of Uvalue limits. Finally, two comparative analysis have been conducted, comparing Aeropan's performance with traditional insulation materials (XPS, EPS and Mineral wool) and evaluating the influence on the environmental impacts of the energy source used in the heating system. Considering the results, a set of conclusions devoted to the potential benefits due to the optimization of resources and the fully recyclability of Aeropan, among others, are presented.

\footnotetext{
${ }^{2}$ www.passiv.de
} 


\section{LCA METHODOLOGY}

The life-cycle environmental benefits of each of the stages considered have been estimated following the LCA methodology. As general, this methodology provides a structured analysis of inputs and outputs at each stage of the life-cycle of products and services (Tukker, 2000). A clear definition of the goal and scope of a study, the system boundaries, the functional unit and the inventory analysis are set in ISO 14040:2006 (International Organisation for Standardisation, 2006a) and ISO 14044:2006 (International Organisation for Standardisation, 2006b). The assessment is performed considering the entire life-cycle of the process, including the extraction and processing of raw materials, manufacturing, transportation, distribution, use, recycling, reuse, and final disposal.

Additionally, since the available Environmental Product Declarations (EPD) are used during the development of the Life Cycle Inventory (LCI) in this study, the product category rules of construction products from the standard EN 15804 (European Committee for Standardization, 2013) are considered. This standard provides the core product category rules for EPD of any construction product and service. Additionally, among its main contents, it defines the conditions under construction products can be compared based on the declared and reported environmental indicators included in an EPD.

\subsection{Goal and scope definition}

The main objective of this study is to estimate the life-cycle environmental benefits linked to the energy efficiency improvement of a nano-technological aerogel based panel for building insulation and its application in a residential dwelling. Thus, the functional unit provides the normalization to allow the comparison of different performance of insulation materials with an equivalent function. Since mass unit doesn't represent the performance of different insulation materials, it is necessary to define a common framework, based on the amount of 
thermal insulation necessary to provide the same thermal resistance, allowing the comparison between different materials (Schmidt et al., 2004). In this sense, the functional unit is the placement of $1 \mathrm{~m}^{2}$ of Aeropan with a thickness of $10 \mathrm{~mm}$ that give a design thermal resistance of $0.667 \mathrm{~m}^{2} \mathrm{~K} / \mathrm{W}$. It should be mentioned that, the selected functional unit allows also the comparison of the impact assessment results with other insulation products EPD, in terms of the different impact categories proposed by the CML-IA baseline (V3.0), aligned with those proposed by EN 15804 for the EPDs and core rules for the product category of construction products. Thus, harmonised and traceable results in environmental impact domain can be obtained.

\subsection{Product description}

Aeropan is a panel designed for thermal insulation of building structures requiring the highest level of insulation in the smallest possible space. It is composed of an insulator nanotechnological Aerogel reinforced with glass fibre (Spaceloft ${ }^{\circledR}$ ) and coupled to a breathable membrane made of polypropylene (SuperLite ${ }^{\circledR}$ ) and is thought for the realization of thermal insulation at low thickness. Spaceloft ${ }^{\circledR}$ is a silica aerogel blanket, fibred reinforced, thermal insulation which takes advantage of the insulating power of air trapped in a nano-porous silica foam matrix. Its base materials are silica (40\%-55\%), PET/glass fibre (20\%-45\%) and additives (0\%-15\%). Its typical properties are presented in the Spaceloft ${ }^{\circledR}$ 's EPD description (Aspen Aerogels, 2015) and the study presented by (Casini, 2016). On the other hand, SuperLite ${ }^{\circledR}$ is a thermoplastic composite sheet composed of a low density polypropylene (20\%), chopped glass-fiber core (70\%), PET scrim attached to both surfaces (5\%) and additives (5\%). Its typical properties and processing overview are presented in the SuperLite ${ }^{\circledR}$ product datasheet and processing sheet (AZDEL, 2002, 2008).

Aeropan is made by AMA COMPOSITES S.R.L., in Modena, Italy through a Lightweight Reinforced Thermoplastic (LWRT) low pressure moulding production process. In addition, 
Table 1 presents the main Aeropan technical specifications. Due to the Aeropan's characteristics with a thickness of only $10 \mathrm{~mm}$ and a thermal conductivity of $0.015 \mathrm{~W} / \mathrm{mK}$, Aeropan reduces energy loss, saving space in building applications, residential and commercial.

\subsection{Target Building}

A representative dwelling in a residential block of buildings is considered as a case study for its façade retrofitting by both, external or internal thermal insulation. This residential block of buildings (total surface around $1,598 \mathrm{~m}^{2}$ ) is located in the City of Zaragoza in Spain. Table 2 presents the main characteristics of the dwelling under study. In addition, its place and internal distribution within the residential block of buildings is presented in Figure 1.

Additionally, the surface of the external wall is $71.86 \mathrm{~m}^{2}$ with a heat transfer coefficient without thermal insulation of (U-value) $1.498 \mathrm{~W} / \mathrm{m}^{2} \mathrm{~K}$ (baseline scenario). The composition of the façade is presented in Table 3 .

It should be mentioned that external windows have a glazing type with a layer of $6 \mathrm{~mm}$, a solar transmission (SHGC) of $0.85, \mathrm{U}$-value $\left(\mathrm{W} / \mathrm{m}^{2} \mathrm{~K}\right)$ of 5.7 , a metallic frame and windows shading with curtains in the inside with manual control.

This representative dwelling and its variations in the different scenarios considered in the manuscript have been modelled using DesignBuilder software (V4.6) ${ }^{3}$. This software consists of a compete interface for the energy simulation engine EnergyPlus ${ }^{4}$. The main inputs needed for the simulation are the location (related to the weather conditions), the HVAC systems, the thermal envelope materials, the operating hours considering the type of activity and use profile,

\footnotetext{
${ }^{3}$ www.designbuilder.co.uk

${ }^{4}$ www.energyplus.net
} 
including the occupancy rates, among others. As a result, it can be estimated the dwelling energy demand for heating and cooling, and the final energy consumption taking into account the efficiency rates of the HVAC systems. The results from the analysis of the baseline scenario (the dwelling without thermal insulation) for heating demand $\left(\mathrm{kWh} / \mathrm{m}^{2}\right.$ year), cooling demand $\left(\mathrm{kWh} / \mathrm{m}^{2}\right.$ year) and final energy consumption for heating $\left(\mathrm{kWh} / \mathrm{m}^{2}\right.$ year) are $78.23,32.77$ and 85.03, respectively. It should be noted that, since a cooling system is not considered, an estimated average seasonal performance factor for the reference heating system of 0.92 , with natural gas as fuel, is taken in to account.

The simulations have been conducted under different conditions according to the Heating Degree-Days (HDD), based on the European Heating Index (EHI) (ECOHEATCOOL project Work Package 1, 2005), and the 5 European climate zones proposed by (Hermelink et al., 2013). It should be noted that these climate zones are based on i) global radiation, ii) heating degreedays, iii) cooling degree-days, and iv) cooling potential by night ventilation. Thus, one representative city per climatic zone has been selected: Athens-Greece (climate zone 1, $\mathrm{HDD}=726$, EHI=62.3), Madrid-Spain (climate zone 2, HDD=1,388, EHI=85.7), Bolzano-Italy (climate zone 3, $\mathrm{HDD}=1,941, \mathrm{EHI}=99.5$ ), Berlin-Germany (climate zone 4, HDD=2,501, $\mathrm{EHI}=103.5$ ) and Stockholm-Sweden (climate zone 5, HDD=3,141, EHI=117.2). It should be mentioned that EHI of Bolzano has been estimated from the values presented by (Werner, 2006).

\subsection{System description}

Table 4 presents the life-cycle stages of the product considered according to the EN 15804 standard classification. In this sense, for the product stage (A1-A3), the main raw materials $\left(\right.$ Spaceloft $^{\circledR}$ and SuperLite $\left.{ }^{\circledR}\right)$ have a transportation distance to AMA COMPOSITES S.R.L. of $6,380 \mathrm{~km}$ and 7,204 km, being the may type of transportation the container ship (tare weight of 24,500t-39,906t) and vessel (tare weight of 30,000t), respectively. As mentioned in the product description section, Aeropan is produced by an innovative LWRT low pressure 
moulding production process, resulting in $1,400 \times 720 \mathrm{~mm}$ panel ready for installation. At manufacturing stage in AMA COMPOSITES S.R.L. premises, all materials, products and energy, as well as waste processing up to the end-of-waste state or disposal of final residues including any packaging not leaving the factory gate with the product is gathered. Once the product leaves the production line is packaged in cardboard boxes, film and storage in pine wood pallets. These last materials are locally supplied with a transportation distance less than $50 \mathrm{~km}$ and assuming a Euro III truck. Figure 2 shows the main processes considered for the Aeropan production.

\subsection{Boundaries of the system}

In general, the components weighting more than $1 \%$ of the final weight of the product, and the second-order boundaries (e.g. production of energy and raw materials for each component) are considered. On the other hand, components representing less than $1 \%$ of the total economic value of the product, less than $1 \%$ of the inventory analysis or less than $1 \%$ of the total environmental impact (e.g. internal transportations, internal storages and small amounts of lubricants), are not considered. It should be noted that the sum of the excluded flows not exceed $5 \%$ of the total materials considered in the Life Cycle Inventory (LCI). Finally, third-order limits (e.g. the infrastructure and the production of the materials required for their implementation) and the stages beyond these limits as the manufacture of the machinery for construction and installations purposes and personnel, are not considered in the study.

\subsection{LCI and quality data}

In order to characterise the different stages considered in the system description within the established boundaries, a proper inventory analysis of the different Aeropan raw materials for the product stage was made. Additionally, for its corresponding modules A1-A3, the primary 
data was gathered from a basic analysis made with AMA COMPOSITES S.R.L., in Modena, Italy, and several questionnaires. Except for production stage, which describe the manufacture of Aeropan and encompasses already known modules A1 to A3; for the calculation of the following modules, realistic and representative assumptions were assumed. On the other hand, with the aim to complete the information gathered, Ecoinvent database (V3.01), European Life Cycle Database (ELCD) (V2.0) and the available environmental product declarations (EPD), were used for the development of the corresponding stage inventories taking into account a maximum of 10 years for generic data. It should be noted that the primary source for obtaining the impact assessment results of Spaceloft ${ }^{\circledR}$ is its corresponding EPD (Aspen Aerogels, 2015). Considering that the mentioned databases contains average data, its applicability to a specific geographic location depends on the level to which its specific characteristics are adapted to these averages (e.g. the estimation of the energy inputs considering the electricity generation mix by fuels, manufacture technology, origin of the raw materials, local transportations, among others). Additionally, in this study the use of the aforementioned databases was carried out considering a static focus.

Table 5 summarizes the LCI per functional unit for the product, construction process, use and end-of-life stages. It should be mentioned that this table was developed based on the goal and scope definition, product description, boundaries of the system, and results of the data collection, considering also the target building under study. The year of the reference is 2016, thus, Aeropan's annual production is considered for this reference year.

Allocation is based on product specific data on the basis of mass allocation. In addition, for the case study of Aeropan's integration in the representative dwelling described in section 2.3, a transportation distance from AMA COMPOSITES S.R.L. to the residential block of buildings of 1,405 km, is considered. Thus, a transportation in a lorry 7.5-16t, EURO5/RER U is assumed. For the transport and logistic (stage A4-Transport gate to site), Aeropan does not 
need any special condition for storage and transport. Also, it should be mentioned that no empty return is considered for the Aeropan's transportation. For the use stage (stages B1-B7), none repair, maintenance, replacement, refurbishment or direct energy or water use is needed during 50 years.

The end-of-life stage of the Aeropan starts when it is replaced, dismantled or deconstructed from the building and does not provide any further functionality (it can start at the end-of-life of the building). Thus, it is important to note that currently in Spain more than $80 \%$ of the Construction and Demolition Waste is disposed of in dumps, so direct or partial recycling is clearly a minority. In case of Subproduct 1 (Hard scrap -mainly Superlite ${ }^{\circledR}+$ traces of $^{2}$ Spaceloft ${ }^{\circledR}$ PET-), this fraction is sent to a recycling facility. A fully recovery of this material is considered, thus a $100 \%$ of recyclability is assumed according the technical description of Aeropan. Additionally, a distance of $20 \mathrm{~km}$ and truck lorry of $20-28 \mathrm{t}$, as described in the Ecoinvent V3.01, is considered. Finally, it should be mentioned that the end-of-life of Aeropan panel corresponds to the same scenario of waste generation and management (Subproduct 1 and Subproduct 2) for the Aeropan's production.

\subsection{Life Cycle Impact Assessment}

The EPD of Spaceloft ${ }^{\circledR}$ aerogel insulation was developed according to ISO 14025:2006 (International Organization for Standardization, 2006) and EN 15804 covering the information modules A1 to A3 (cradle to gate). Based on this EPD, the modules A4 and A5 corresponding to construction process stage are considered for the target building described. Also, the modules B1-B7 and C1-C4 are included to the analysis from the description made in the LCI and quality data section. In this sense, since this EPD has been assessed by CML methodology and its necessary to harmonise the results considering the Aeropan's production life-cycle stages, the characterisation factors applied to each impact category correspond to those proposed by the CML-IA baseline (V3.0), which is an update of the CML 2 baseline 
2000 (V2.05) methodology for Life Cycle Impact Assessment (LCIA), at midpoint-level using the Software SimaPro v.8.0.1 (Guinée, 2002; Rebitzer et al., 2004). A short description of the teen impact categories considered by CML 2 impact assessment methodology is presented in the studies developed by (Banar et al., 2009; Bravo et al., 2012). From these impact categories, in line with the impact categories proposed by EN 15804, the following seven midpoint indicators are considered: Global warming potential $\left(\mathrm{kg} \mathrm{CO}_{2} \mathrm{eq}\right)$, Ozone depletion potential ( $\mathrm{kg}$ CFC-11 eq), Acidification potential $\left(\mathrm{kg} \mathrm{SO}_{2} \mathrm{eq}\right)$, Eutrophication potential $\left(\mathrm{kg}\left(\mathrm{PO}_{4}\right)^{3-} \mathrm{eq}\right)$, Photochemical ozone creation potential ( $\mathrm{kg} \mathrm{C}_{2} \mathrm{H}_{4}$ eq), Abiotic depletion potential (elements) (kg Sb eq) and Abiotic depletion potential (fossil fuels) (MJ). On the other hand, the primary energy demand (MJ-eq) is estimated according to the Cumulative Energy Demand (CED) method (V.1.08). CED distinguishes between nonrenewable and renewable primary energy use (Frischknecht and Jungbluth, 2003).

\subsection{Analysis of the influence of the system boundary chosen}

According to the classification of the life-cycle stages of the product presented in Table 4, the LCA boundaries of Aeropan can be defined either from cradle to gate (including extraction and processing of raw materials and the production of the final product: A1 to A3), from cradle to grave (from A1 to $\mathrm{C} 4$ ) and from cradle to cradle (from A1 to $\mathrm{C} 4$, including the module D of benefits and loads beyond the system boundaries). Two approaches are considered for the assessment developed of the case study in this paper: firstly, a holistic approach considering a cradle to gate analysis of Aeropan (corresponding to modules A1 to A3); and secondly a cradle to grave approach (from modules A1 to C4), quantifying the net environmental benefits related to the reduction of the energy demand during the use phase and end-of-life of the building.

Most EPD for products accounts for the materials, energy and emissions related to its product stage (A1-A3), considering that there are many possibilities (including transport) for the use 
of the product after leaving the plant gate. Thus, most manufacturers account their products' environmental impacts from a cradle to gate approach. This is the case of the Spaceloft ${ }^{\circledR}$ EPD where environmental impacts results are presented at product stage level (A1-A3) plus transport module (A4), after the inclusion of a transport to the building site scenario.

In order to present the results in terms of impact assessment benefits of the Aeropan's building integration as internal and external insulation in façade, which represents the environmental impact associated with production of Aeropan versus the reduction in energy demand of the building considering a life time of use of the building, a cradle to grave approach (A1 to $\mathrm{C} 4$ ) should be considered. Cradle to grave approach analysis is the most representative accounting for building's material environmental assessment, because the higher environmental impacts of buildings are usually related to their use phase. In case of insulation materials, it is during the building use phase that net benefits can be obtained with its integration, considering the energy savings and related impacts, e.g., for heating. In addition, for the end-of-life stage ( $\mathrm{C} 1$ to $\mathrm{C} 4)$ a proper scenario should be considered having in mind that the reference service life of insulation material can be less than the building's life span. In case of Aeropan, a working life of 50 years is assumed.

\section{RESULTS AND DISCUSSION}

Based on the LCI, Table 6 presents the results of the environmental implications from a cradle to gate approach for $1 \mathrm{~m}^{2}$ of Aeropan with a thickness of $10 \mathrm{~mm}$. Also, Figure 3 presents the environmental implications of the main processes from a cradle to gate approach. From the results, it should be mentioned that Spaceloft ${ }^{\circledR}$ product stage represents, in percentage of the total Aeropan's impact, as follows: Global warming potential $(76.45 \%)$, Ozone depletion potential (91.39\%), Acidification potential (68.07\%), Eutrophication potential (41.01\%), Photochemical ozone creation potential (78.46\%), Abiotic depletion potential (elements) (93.31\%), Abiotic 
depletion potential (fossil fuels) (80.59\%), Non-renewable primary energy use (83.87\%) and Renewable primary energy use $(88.82 \%)$. In terms of $\mathrm{kg} \mathrm{CO}_{2}$ eq, the main contributors are Spaceloft ${ }^{\circledR}$ followed by electricity consumption for Aeropa's production process and SuperLite ${ }^{\circledR}$. Zabalza et al. (2011), have developed an LCA study comparing the most commonly used insulation materials: EPS foam slab, rock wool, polyurethane rigid foam, cork slab, cellulose fibre and wood wool. Results show that the impact of materials with a high level of industrial processing, e.g., EPS, is higher in comparison of natural materials, e.g. cork (Zabalza Bribián et al., 2011). In this case, as previously mentioned, the main Aeropan's impacts in terms of kg $\mathrm{CO}_{2}$ eq are related to the product stage of Spaceloft ${ }^{\circledR}$. In this sense, in terms of the Spaceloft ${ }^{\circledR}$ s embodied $\mathrm{CO}_{2}$ eq, silica precursor and other raw materials, fibrous reinforcement, production process and pollution control equipment, accounts for $75.65 \%, 14.18 \%, 9.46 \%$ and $0.71 \%$, respectively, of the total impact; being that supercritical extraction embodied $\mathrm{CO}_{2}$ eq is recovered from other industrial processes (Casini, 2016). In case of electricity consumption for Aeropan's production process, an improvement of the impact assessment can be easily done by producing $2 \mathrm{~m}^{2}$ per production cycle instead of $1 \mathrm{~m}^{2}$. Since electricity is mainly used for the heating and moulding/cutting process, an improvement of the results can be made with the optimization of the space available in these equipment. This can lead to a reduction of $5.59 \%$ of the total impact in terms of $\mathrm{kg} \mathrm{CO} 2 \mathrm{eq} / \mathrm{m}^{2}$.

On the other hand, Table 7 presents the results from the analysis of the case study with the inclusion of Aeropan as internal and external insulation in façade.

From the results shown in Table 6, and considering the methodology presented by Dylewski et al. (2014) for the estimation of the environmental cost associated with production of insulating materials versus the reduction in energy demand of the building, Table 8 presents the results for the impact assessment benefits of the Aeropan's integration as internal and external insulation in façade considering a life time of use of the building of 50 years, considering a cradle to grave 
approach. It is important to note that positive values represent net benefits with the integration of Aeropan considering the energy savings for heating in terms of the impacts related to natural gas consumption.

\section{SCENARIO ANALYSIS}

Several analysis have been conducted to evaluate the performance of Aeropan under different conditions and with different approaches: first of all, a simulation and comparison of the energy performance of Aeropan integration in a building under different climate zones; the behaviour of heating demand, in the different locations assessed, using different U-values achieved by extra Aeropan's thickness integration; the influence in the environmental impacts reduction of using different heating sources and, lastly, the comparison with other traditional insulation materials in terms of thickness and U-value achieved, considering the limits set in the different locations considered.

\subsection{Comparative analysis of different locations of the baseline scenario + Aeropan's integration}

Table 9 presents the variations on the heating demand (cooling system is not considered in the representative dwelling) for the baseline scenario with Areropan's integration related to the different locations proposed. The percentage of reduction of the heating demand $\left(\mathrm{kWh} / \mathrm{m}^{2}\right.$ year) for the hypothetical locations of the case study are presented for each case with reference of the baseline scenario (w/o insulation). In addition, it should be mentioned that the Aeropan thickness is $10 \mathrm{~mm}$.

Additionally, Table 10 presents the results for the impact assessment benefits of the Aeropan's integration as internal and external insulation in the hypothetical locations. As can be noted, the use of Aeropan in locations with higher HDD brings better environmental performances, mainly 
in terms Global Warming Potential (GWP), while other indicators less dependent on energy consumption are therefore less sensitive to the HDD of the location.

\subsection{Analysis of the heating demand reduction in the selected locations due different U-values with Aeropan}

Table 11 and Figure 4 present the comparative scenarios of heating demand for the hypothetical locations considering different U-value achieved by Aeropan's integration with its increasing of thickness. Based on the results presented in Table 7 and Table 9, it should be noted that the dwelling with Aeropan as external insulation has a lower heating demand value in comparison to the same dwelling with Aeropan as internal insulation. Also, from the results presented in Table 10, the external insulation has higher net benefits in comparison to the internal insulation regardless of the dwelling location. Thus, the results presented in Table 11 are only referred to the external insulation case.

Results presented in Figure 4 show the highest reduction when moving from the base scenario (no insulation) to the $10 \mathrm{~mm}$ thickness of Aeropan insulation (U-value $=0.749 \mathrm{~W} / \mathrm{m}^{2} \mathrm{~K}$ ). It can be noted that, from $10 \mathrm{~mm}$ on, higher thicknesses do not bring significant levels of heating demand reductions, reaching quite soon the asymptote.

Based on the data presented in Table 11, Figure 5 presents the energy savings achieved by different Aeropan thickness. As can be observed in Figure 5, energy savings are drastically reduced when using $20 \mathrm{~mm}$ of Aeropan, in comparison with the savings achieved by $10 \mathrm{~mm}$ thickness scenario. Savings reached by progressively increasing thickness by $10 \mathrm{~mm}$ are sharply decreasing to zero.

\subsection{Comparative analysis of different fuels for heating}

A comparative analysis of the impact assessment benefits of the Aeropan's integration as internal and external insulation in the Madrid case is presented in Table 12. Electricity and diesel are 
considered as alternative fuels for heating. It should be noted that an estimated average seasonal performance factor for the reference heating system of 0.92 and 1, with diesel and electricity, respectively is considered. From the results presented in Table 12, it can be observed that the greatest net benefits are obtained if electricity is used for heating, followed by the diesel and natural gas.

\subsection{Comparative analysis of Aeropan and conventional insulation materials}

A comparative analysis of Aeropan and the following conventional insulation materials: EPS, XPS and Mineral Wool, is presented in Figure 6 considering the baseline scenario (ZaragozaSpain) with internal insulation of the proposed materials, whose main characteristics are presented in Table 13. The figure shows the wall's U-value achieved by different thickness of the insulating materials assessed, together with the U-value limits set by the different national regulations, summarized in Table 14.

As can be noted, there are significant differences between U-values established by the different national regulations, which result in notably higher requirements in terms of thickness needs in climate zones 3, 4 and 5. The lower the U-value limit is, the higher the thickness, and the broader the difference between Aeropan thickness needed and the other traditional materials assessed, as the U-value goes asymptotic. As an example, considering the U-value limit for Zone 4, $0.05 \mathrm{~m}$ of Aeropan would meet the requirements, while $0.12 \mathrm{~m}$ of XPS, $0.16 \mathrm{~m}$ of EPS or $0.17 \mathrm{~m}$ of mineral wool would be needed to achieve the same insulation level.

\section{CONCLUSIONS}

The results presented in this study show that Aeropan provides net benefits in terms of Global Warming Potential for the internal and external insulation of the building, respectively, considering a non-insulated base case if natural gas is used as energy source. Better results are achieved regardless of the location by an external use of Aeropan and when the use of 
electricity or diesel as heating source is considered. In addition, higher reductions of the environmental indicators related to energy consumption are achieved in the locations with higher HDD. In this sense, it should be mentioned that the reduction of the energy demand, due to the Aeropan's integration determines the final benefits. These benefits are also affected by the different type of fuel used.

Related to the cradle to gate approach, since the main Aeropan's impacts are related to the product stage of Spaceloft ${ }^{\circledR}$, a future work to be developed is to analyse the production processes of Spaceloft ${ }^{\circledR}$ given its potential of improvement as a new technological material available in the market. Considering that PET/glass fibre represents a range of $20-45 \%$ of the total base materials of Spaceloft ${ }^{\circledR}$, a research work to be developed with manufacturer is the possibility to include recycled materials. In this line of work, the environmental impacts during the production of aerogel should be extensively explored. In addition, since the novelty of Aeropan's production line, only static data were collected during on-site visit and through several questionnaires, however, it is recommended to monitor the collected information in order to determine deviations which may influence in the environmental results. In this sense, at least one-year data collection is needed to evaluate the fluctuations and deviations of the main inputs and outputs of the product system.

From the results of the comparative analysis of Aeropan vs EPS, XPS and Mineral Wool in terms of the U-value and thickness, when the passive house requirements of façade thermal insulation are considered (with thermal transmittance values in the range between 0.1 to 0.15 $\left.\mathrm{W} / \mathrm{m}^{2} \mathrm{~K}\right)$, a reasonable thickness of insulation material is available only with Aeropan. Using conventional insulating materials for the proposed values of thermal transmittance, the thickness needed is considerable higher, demonstrating that Aeropan reduces the thickness needed due to its low thermal conductivity, resulting in a significant reduction of the space needed by the insulating solution. EPS and mineral wool, result in massive wall solutions. 
Therefore, Aeropan appears to be especially suitable for the refurbishment of existing buildings in which traditional solutions are not feasible due to the space needed for the insulating solution. Thus, a good solution to reduce the thickness of the insulation material is through products based on aerogel (e.g. Aeropan) and vacuum insulation. However, these new materials are notoriously energy intensive in production, resulting in high levels of embodied energy and emissions, also presented in the EPD of Spaceloft ${ }^{\circledR}$.

Although commercial panels are firstly available with $10 \mathrm{~mm}$ thickness, the simulation of an increased thickness used in the five climate zones have been performed, indicating that the environmental improvement achieved is drastically reduced from $20 \mathrm{~mm}$ thickness on.

The results obtained in the analysis developed in this paper serves as the basis to implement future improvements in the different phases of Aeropan's life-cycle, including an analysis of the cradle to cradle approach (from A1 to C4, including the module D of benefits and loads beyond the system boundaries), contributing to a continuous improvement programme in order to reduce the impacts generated during the production of its components (mainly Spaceloft $\left.{ }^{\circledR}\right)$, commercialization and recovery of by-products.

\section{ACKNOWLEDGMENTS}

This contribution has been developed in the framework of the 'Prefabricated AEROgel based PANel with superior performance for building insulation'- AEROPAN project (Grant Agreement ECO/12/332844) co-financed by the European Commission under the CIP-Eco innovation Programme.

\section{REFERENCES}

Asdrubali, F., D'Alessandro, F., Schiavoni, S., 2015. A review of unconventional sustainable building insulation materials. Sustainable Materials and Technologies 4, 1-17. 
Aspen Aerogels, I., 2015. SPACELOFT® AEROGEL INSULATION. Environmental Product Declaration according to ISO 14025 and EN 15804. The International EPD® System. Declaration number S-P-00725.

AZDEL, I., 2002. Processing Sheet, AZDEL SuperLite Thermoplastic Composites, http://www.hanwhaazdel.com/images/PDFs/tech-support/SuperLite_Processing_Sheet.pdf.

AZDEL, I., 2008. Product Datasheet, AZDEL SuperLite VGX SLVGXB.1BP027, http://www.hanwhaazdel.com/images/PDFs/tech-support/Datasheet_-_SLVGX-1BP027.pdf.

Baetens, R., Jelle, B.P., Gustavsen, A., 2011. Aerogel insulation for building applications: A state-of-the-art review. Energy and Buildings 43, 761-769.

Banar, M., Cokaygil, Z., Ozkan, A., 2009. Life cycle assessment of solid waste management options for Eskisehir, Turkey. Waste Management 29, 54-62.

Bravo, Y., Carvalho, M., Serra, L.M., Monné, C., Alonso, S., Moreno, F., Muñoz, M., 2012. Environmental evaluation of dish-Stirling technology for power generation. Solar Energy 86, 2811-2825.

Cabeza, L.F., Castell, A., Medrano, M., Martorell, I., Pérez, G., Fernández, I., 2010. Experimental study on the performance of insulation materials in Mediterranean construction. Energy and Buildings 42, 630-636.

Casini, M., 2016. 4 - Advanced insulating materials, Smart Buildings. Woodhead Publishing, pp. 127-177.

Commission of the European Communities (COTEC), 2008. Commission staff working document - accompanying document to the proposal for a recast of the energy performance of buildings directive (2002/91/EC) — summary of the impact assessment. vol COM (2008) 780 final. European Commission.

CTE DB-HE, 2013. Technical Building Code Basic Document-Basic Requirements Energy Saving. Ministry of Development: Madrid, Spain, (accessed on 2 February 2016).

Cuce, E., Cuce, P.M., Wood, C.J., Riffat, S.B., 2014a. Optimizing insulation thickness and analysing environmental impacts of aerogel-based thermal superinsulation in buildings. Energy and Buildings 77, 28-39.

Cuce, E., Cuce, P.M., Wood, C.J., Riffat, S.B., 2014b. Toward aerogel based thermal superinsulation in buildings: A comprehensive review. Renewable and Sustainable Energy Reviews 34, 273-299.

ECOHEATCOOL project Work Package 1, 2005. The European Heat Market. Final Report, https://www.euroheat.org/wp-content/uploads/2016/02/Ecoheatcool_WP1_Web.pdf.

European Commission, 2010. Directive 2010/31/EU of the European Parliament and of the Council of 19 May 2010 on the energy performance of buildings. Official Journal of the European Union, 13-35.

European Commission, 2013. Energy-efficient buildings: multi-annual roadmap for the contractual PPP under Horizon 2020. Energy-efficient Buildings: Multi-annual Roadmap for the Contractual PPP under Horizon 2020.

European Committee for Standardization, 2013. EN 15804:2012+A1: 2013. Sustainability of Construction Works - Environmental Product Declarations - Core Rules for the Product Category of Construction Products. 
European Union, 2012. Directive 2012/27/EU of the European Parliament and of the Council of 25 October 2012 on energy efficiency, amending Directives 2009/125/EC and 2010/30/EU and repealing Directives 2004/8/EC and 2006/32/EC. Official Journal of the European Union $315,1-56$.

Frischknecht, R., Jungbluth, N., 2003. Implementation of life cycle impact assessment methods. Implementation of Life Cycle Impact Assessment Methods.

Guinée, J.B., 2002. Handbook on Life Cycle Assessment: Operational Guide to the ISO Standards. Springer.

Hermelink, A., Schimschar, S., Boermans, T., Pagliano, L., Zangheri, P., Armani, R., Voss, K., Musall, E., 2013. Towards Nearly Zero-energy Buildings: Definition of Common Principles under the EPBD. ECOFYS Germany GmbH.

Hostler, S.R., Abramson, A.R., Gawryla, M.D., Bandi, S.A., Schiraldi, D.A., 2009. Thermal conductivity of a clay-based aerogel. International Journal of Heat and Mass Transfer 52, 665-669.

IAL Consultants, 2015. The european market for thermal insulation products, http://www.ialconsultants.com/uploads/CUBE_press_release/2015-07-

15/EUThermal\%20Ins\%20press\%20release\%202015.pdf.

International Energy, A., 2013. Technology Roadmap: Energy Efficient Building Envelopes.

International Organisation for Standardisation, 2006a. ISO 14040:2006, Environmental Management - Life Cycle Assessment - Principles and Framework, International Organization for Standardization, Geneva, Switzerland

International Organisation for Standardisation, 2006b. ISO 14044:2006, Environmental Management - Life Cycle Assessment - Requirements and guidelines, International Organization for Standardization, Geneva, Switzerland

International Organization for Standardization, 2006. ISO 14025:2006. Environmental labels and declarations -- Type III environmental declarations -- Principles and procedures.

Jelle, B.P., 2011. Traditional, state-of-the-art and future thermal building insulation materials and solutions - Properties, requirements and possibilities. Energy and Buildings 43, 25492563.

Moretti, E., Belloni, E., Agosti, F., 2016. Innovative mineral fiber insulation panels for buildings: Thermal and acoustic characterization. Applied Energy 169, 421-432.

Papadopoulos, A.M., 2005. State of the art in thermal insulation materials and aims for future developments. Energy and Buildings 37, 77-86.

Pardo, N., Vatopoulos, K., Krook-Riekkola, A., Moya, J.A., Perez, A., 2012. Heat and Cooling Demand and Market Perspective. European Commission-Joint Research Centre, Institute for Energy and Transport.

Pombo, O., Rivela, B., Neila, J., 2016. The challenge of sustainable building renovation: assessment of current criteria and future outlook. Journal of Cleaner Production 123, 88-100.

Proietti, S., Desideri, U., Sdringola, P., Zepparelli, F., 2013. Carbon footprint of a reflective foil and comparison with other solutions for thermal insulation in building envelope. Applied Energy 112, 843-855.

Rebitzer, G., Ekvall, T., Frischknecht, R., Hunkeler, D., Norris, G., Rydberg, T., Schmidt, W.P., Suh, S., Weidema, B.P., Pennington, D.W., 2004. Life cycle assessment: Part 1: 
Framework, goal and scope definition, inventory analysis, and applications. Environment International 30, 701-720.

Schmidt, A.C., Jensen, A.A., Clausen, A.U., Kamstrup, O., Postlethwaite, D., 2004. A comparative life cycle assessment of building insulation products made of stone wool, paper wool and flax. The International Journal of Life Cycle Assessment 9, 122-129.

Sierra-Pérez, J., Boschmonart-Rives, J., Gabarrell, X., 2016. Environmental assessment of façade-building systems and thermal insulation materials for different climatic conditions. Journal of Cleaner Production 113, 102-113.

Silvestre, J.D., de Brito, J., Pinheiro, M.D., 2014. Environmental impacts and benefits of the end-of-life of building materials - calculation rules, results and contribution to a "cradle to cradle" life cycle. Journal of Cleaner Production 66, 37-45.

Sohn, J.L., Kalbar, P.P., Banta, G.T., Birkved, M., 2017. Life-cycle based dynamic assessment of mineral wool insulation in a Danish residential building application. Journal of Cleaner Production 142, Part 4, 3243-3253.

Su, X., Luo, Z., Li, Y., Huang, C., 2016. Life cycle inventory comparison of different building insulation materials and uncertainty analysis. Journal of Cleaner Production 112, Part $1,275-281$.

Tukker, A., 2000. Life cycle assessment as a tool in environmental impact assessment. Environmental Impact Assessment Review 20, 435-456.

Walker, R., Pavía, S., 2015. Thermal performance of a selection of insulation materials suitable for historic buildings. Building and Environment 94, Part 1, 155-165.

Wei, G., Liu, Y., Zhang, X., Yu, F., Du, X., 2011. Thermal conductivities study on silica aerogel and its composite insulation materials. International Journal of Heat and Mass Transfer 54, 2355-2366.

Werner, S., 2006. The new European heating index, In: 10th International Symposium on District Heating and Cooling, Hannover, Germany.

Zabalza Bribián, I., Aranda Usón, A., Scarpellini, S., 2009. Life cycle assessment in buildings: State-of-the-art and simplified LCA methodology as a complement for building certification. Building and Environment 44, 2510-2520.

Zabalza Bribián, I., Valero Capilla, A., Aranda Usón, A., 2011. Life cycle assessment of building materials: Comparative analysis of energy and environmental impacts and evaluation of the eco-efficiency improvement potential. Building and Environment 46, 1133-1140. 


\section{TABLE CAPTION}

Table 1. Aeropan technical specifications

Table 2. Main dwelling characteristics

Table 3. Composition of the façade

Table 4. Life cycle stages of the product based on the EN 15804:2012+A1:2013

Table 5. Main LCI data

Table 6. Environmental implication from cradle to gate approach for $1 \mathrm{~m}^{2}$ of Aeropan with a thickness of $10 \mathrm{~mm}$

Table 7. Heating and cooling demand of Aeropan's integration internal and external insulation in façade

Table 8. Impact assessment benefits of the Aeropan's integration as internal and external insulation in façade

Table 9. Comparative scenarios of heating demand $\left(\mathrm{kWh} / \mathrm{m}^{2}\right.$ year $)$ for the hypothetical locations of the case study in Athens (Greece), Madrid (Spain), Bolzano (Italy), Berlin (Germany) and Stockholm (Sweden) (Aeropan as external insulation)

Table 10. Results for the impact assessment benefits of the Aeropan's integration as internal and external insulation in façade in the hypothetical locations

Table 11. Comparative scenarios of heating demand $\left(\mathrm{kWh} / \mathrm{m}^{2}\right.$ year $)$ for the hypothetical locations considering different U-value achieved by Aeropan's integration as external insulation 
Table 12. Comparative analysis of the impact assessment benefits of the Aeropan's integration as internal and external insulation in the Madrid case considering natural gas, electricity and diesel as alternative fuels

Table 13. Main characteristics of the conventional insulation materials analysed

Table 14. U-value limits set by the different national regulations

\section{FIGURE CAPTION}

Figure 1. Place and internal distribution of the dwelling under study within the residential block of buildings

Figure 2. Main processes considered for the Aeropan production

Figure 3. Environmental implications (cradle to gate approach) of the main processes for $1 \mathrm{~m}^{2}$ of Aeropan with a thickness of $10 \mathrm{~mm}$

Figure 4. Comparative analysis of heating demand for different U-value achieved by Aeropan as external insulation in the five climate zones

Figure 5. Comparative analysis of energy savings using different Aeropan thickness as external insulation in the five climate zones

Figure 6. Comparative analysis of Aeropan vs EPS, XPS and Mineral Wool as internal insulation considering thermal transmittance values (U-value) limits 


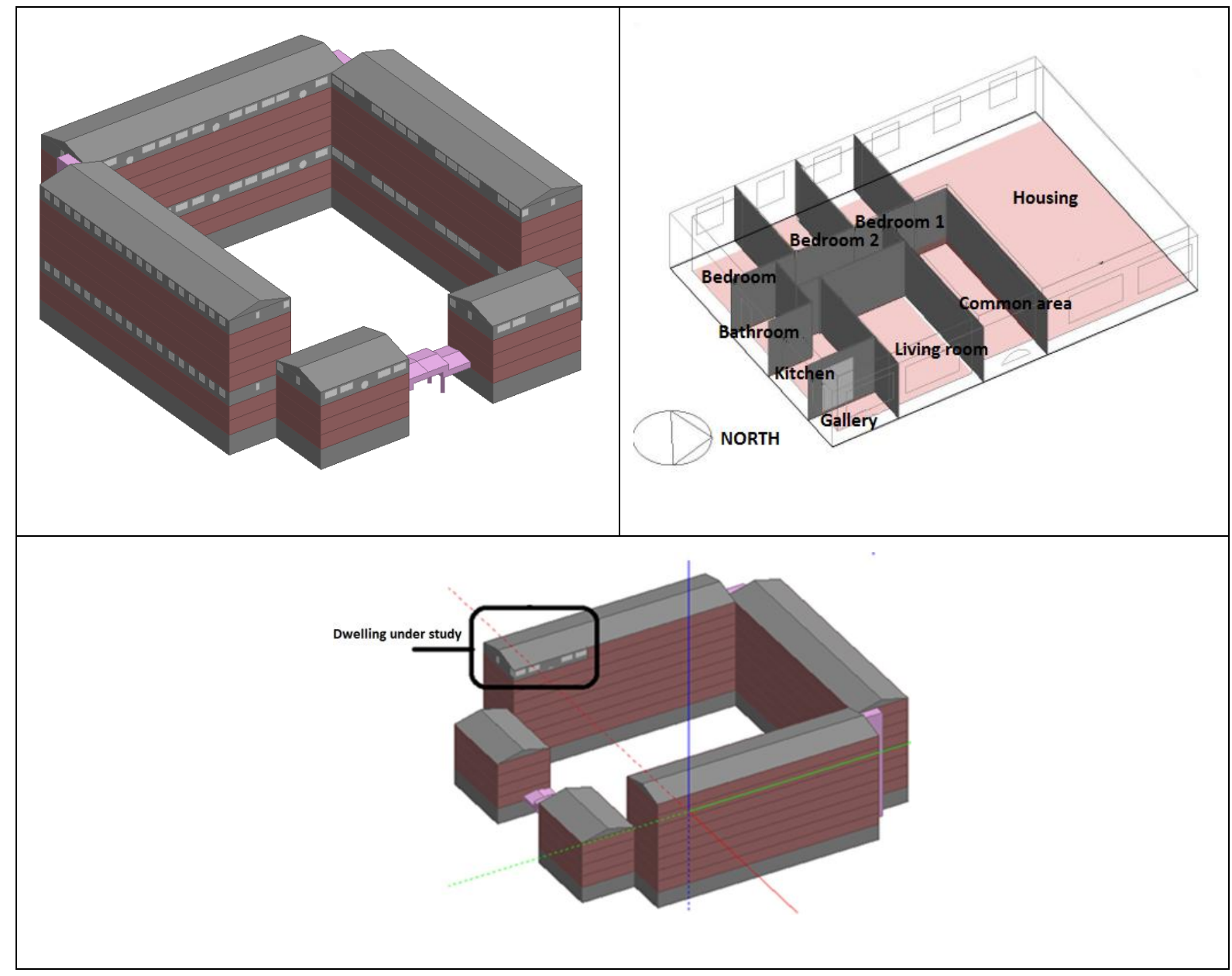

Figure 1. Place and internal distribution of the dwelling under study within the residential block of buildings 


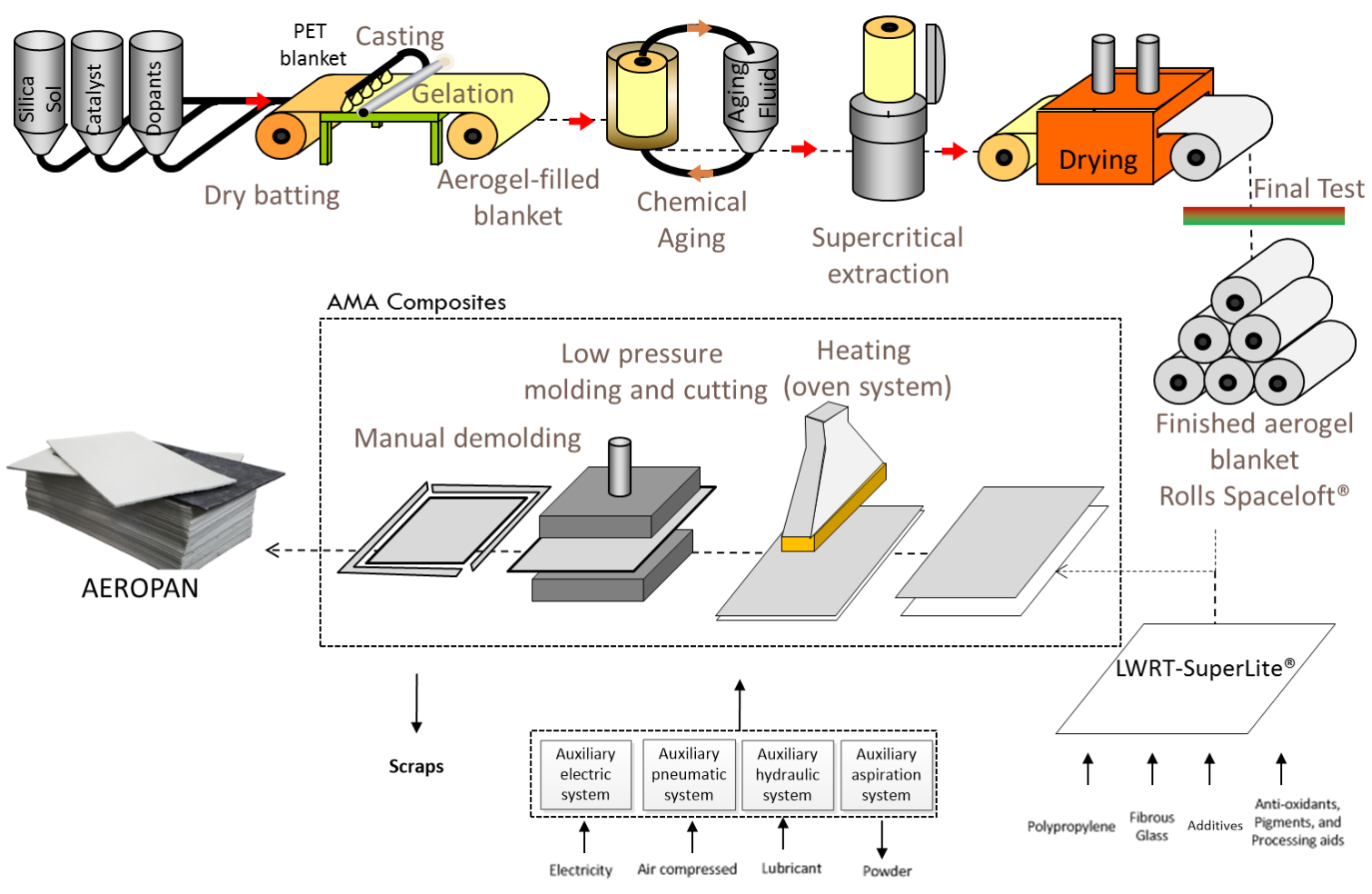

Figure 2. Main processes considered for the Aeropan production 


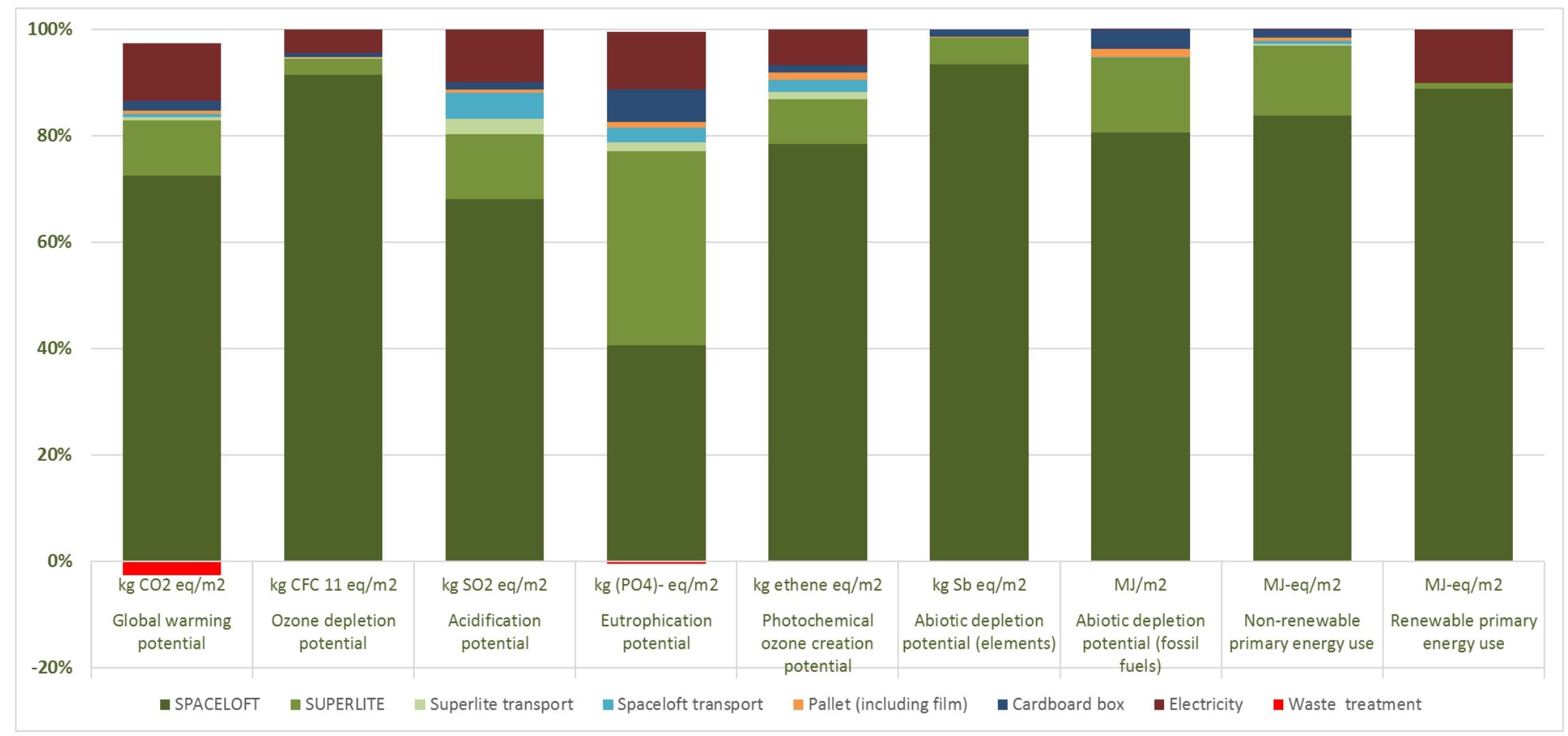

Figure 3. Environmental implications (cradle to gate approach) of the main processes for $1 \mathrm{~m}^{2}$ of Aeropan with a thickness of $10 \mathrm{~mm}$ 


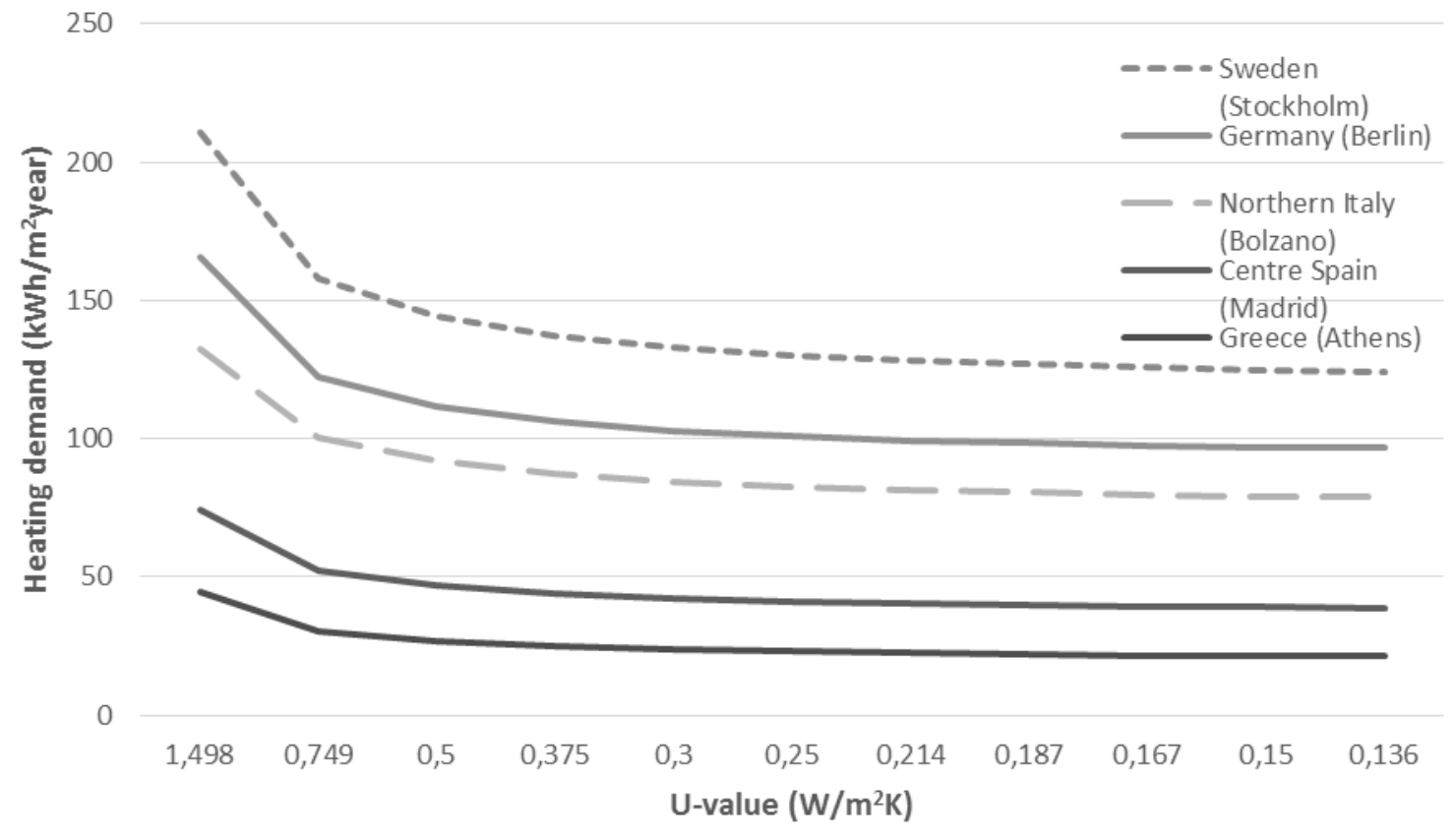

Figure 4. Comparative analysis of heating demand for different U-value achieved by Aeropan as external insulation in the five climate zones 


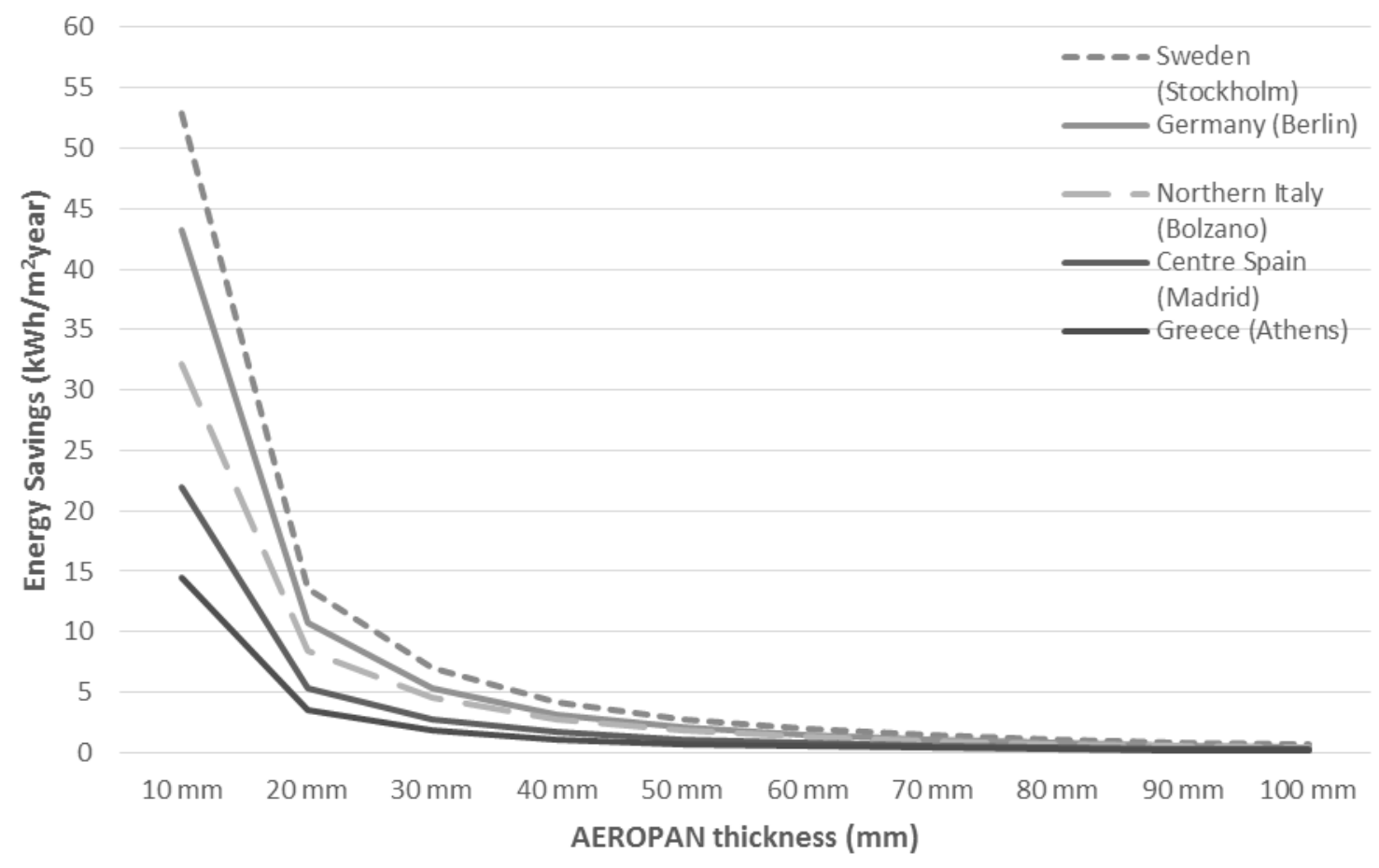

Figure 5. Comparative analysis of energy savings using different Aeropan thickness as external insulation in the five climate zones. 


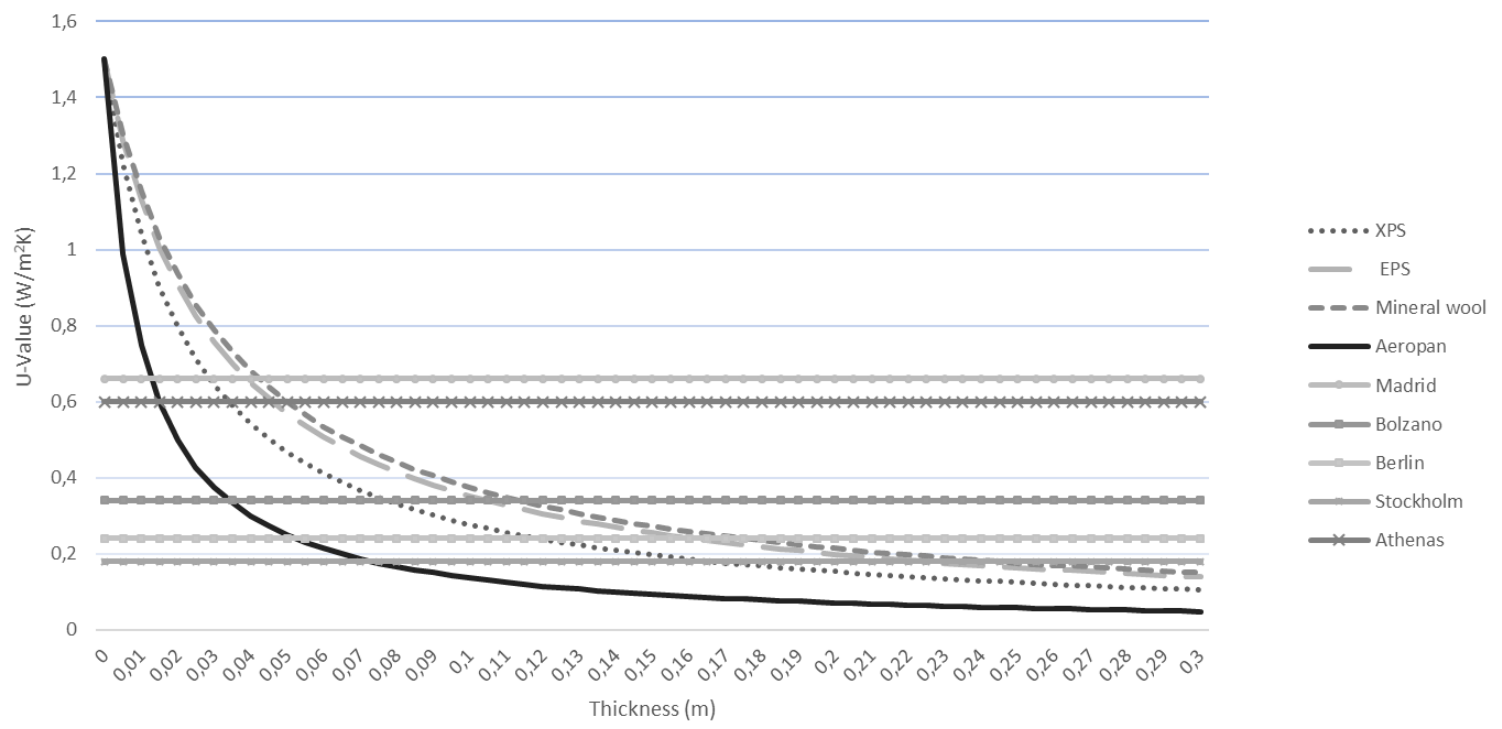

Figure 6. Comparative analysis of Aeropan vs EPS, XPS and Mineral Wool as internal insulation considering thermal transmittance values (U-value) limits. 
Table 1. Aeropan technical specifications

\begin{tabular}{lrrr}
\hline Technical data & Value & Unit & Test method \\
\hline Format & $1,400 \times 720$ & $\mathrm{~mm}$ & - \\
Thickness & 10 & $\mathrm{~mm}$ & - \\
Thermal conductivity at $10{ }^{\circ} \mathrm{C}$ & 0.015 & $\mathrm{~W} / \mathrm{mK}$ & EN12667 \\
Resistance to steam diffusion & 5 & - & EN12086 \\
Temperature of use limitations & $-200+200$ & ${ }^{\circ} \mathrm{C}$ & - \\
Resistance to compression (for & 80 & $\mathrm{kPa}$ & EN826 \\
10\% deformation) & & & \\
Specific heat & 1,000 & $\mathrm{~J} / \mathrm{kgK}$ & ASTM E 1269 \\
Nominal density & $230 \pm 20 \%$ & $\mathrm{~kg} / \mathrm{m}^{3}$ & \\
$\begin{array}{l}\text { Reaction to fire classification } \\
\text { Long term water absorption by }\end{array}$ & $\mathrm{C} \mathrm{S} 1 \mathrm{DD}$ & & $\mathrm{EN} 13501-1$ \\
partial immersion & $\mathrm{Wp} \leq 0.01$ & $\mathrm{~kg} / \mathrm{m}^{2}$ & $\mathrm{EN} \mathrm{1609}$ \\
Color & Gray/White & - & - \\
\hline
\end{tabular}


Table 2. Main dwelling characteristics

\begin{tabular}{lll}
\hline Technical data & Value & Unit \\
\hline Gross total area & 73.0 & $\mathrm{~m}^{2}$ \\
Total floor area & 69.3 & $\mathrm{~m}^{2}$ \\
Floor height & 2.5 & $\mathrm{~m}$ \\
Occupancy & 1 & person \\
Type of activity & Medium metabolic rate & - \\
Heating setpoint & 21 & ${ }^{\circ} \mathrm{C}$ \\
Cooling setpoint & 26 & ${ }^{\circ} \mathrm{C}$ \\
Humidity & $30-70$ & $\%$ \\
Air changes per hour & 0.63 & renovations-hour \\
Azimuth angle (Façade) & 330 & ${ }^{\circ}$ \\
\hline
\end{tabular}


Table 3. Composition of the façade

\begin{tabular}{lcccc}
\hline Layer & $\begin{array}{c}\text { Conductivity } \\
(\mathbf{W} / \mathbf{m K})\end{array}$ & $\begin{array}{c}\text { Specific heat } \\
(\mathbf{J} / \mathbf{k g K})\end{array}$ & $\begin{array}{c}\text { Density } \\
\left(\mathbf{k g} / \mathbf{m}^{\mathbf{3}}\right)\end{array}$ & $\begin{array}{c}\text { Thickness } \\
(\mathbf{m})\end{array}$ \\
\hline Brickwork, outer leaf & 0.84 & 800 & 1,700 & 0.100 \\
Air gap & 0.3 & 1,000 & 1,000 & 0.050 \\
Concrete block (medium) & 0.51 & 1,000 & 1,400 & 0.100 \\
Gypsum plastering & 0.4 & 1,000 & 1,000 & 0.013 \\
\hline
\end{tabular}


Table 4. Life cycle stages of the product based on the EN 15804:2012+A1:2013

\begin{tabular}{ll}
\hline \multicolumn{1}{c}{ Stage } & \multicolumn{1}{c}{ Module } \\
\hline \multirow{3}{*}{ I. Product stage } & A1. Raw material supply \\
& A2. Transport \\
& A3. Manufacturing \\
\hline $\begin{array}{c}\text { II. Construction } \\
\text { process stage }\end{array}$ & A4. Transport gate to the site \\
& A5. Assembly \\
& B1. Use \\
& B2. Maintenance \\
& B3. Repair \\
III. Use stage & B4. Replacement \\
& B5. Refurbishment \\
& B6. Operational energy use \\
& B7. Operational water use \\
\hline & C1. Deconstruction-demolition \\
IV. End-of-life & C2. Transport \\
stage & C3. Waste processing \\
& C4. Disposal \\
\hline
\end{tabular}


Table 5. Main LCI data

\begin{tabular}{|c|c|c|c|c|}
\hline Stage & Item & Value & Unit & Comments \\
\hline \multirow[t]{9}{*}{ Product } & Spaceloft $^{\circledR}$ & 1.78 & $\mathrm{~kg}$ & $\begin{array}{l}\text { Weight of the product. } \\
\text { Inventory includes } \\
\text { transportation and packaging }\end{array}$ \\
\hline & SuperLite $^{\circledR}$ & 0.95 & $\mathrm{~kg}$ & $\begin{array}{l}\text { Weight of the product. } \\
\text { Inventory includes } \\
\text { transportation and packaging }\end{array}$ \\
\hline & Cardboard & 0.2 & $\mathrm{~kg}$ & $\begin{array}{l}\text { Cardboard box for Aeropan } \\
\text { packaging }\end{array}$ \\
\hline & $\begin{array}{l}\text { Polyethylene } \\
\text { extensible film }\end{array}$ & 0.00143 & $\mathrm{~kg}$ & Film for Aeropan packaging \\
\hline & Pine wood pallet & 0.214 & $\mathrm{~kg}$ & Pallet for Aeropan packaging \\
\hline & $\begin{array}{l}\text { Electricity } \\
\text { consumption }\end{array}$ & 2.89 & $\mathrm{kWh}$ & $\begin{array}{l}\text { Electricity consumption } \\
\text { (includes hydraulic, pneumatic } \\
\text { and auxiliary system }+ \\
\text { aspiration system) }\end{array}$ \\
\hline & Lubricant & 0.00270 & $\mathrm{~kg}$ & Lubricant for maintenance \\
\hline & Subproduct 1 & 0.15 & $\mathrm{~kg}$ & $\begin{array}{l}\text { Hard scrap (mainly } \text { Superlite }^{\circledR}+ \\
\text { traces of Spaceloft }^{\circledR} \text { PET) }\end{array}$ \\
\hline & Subproduct 2 & 0.18 & $\mathrm{~kg}$ & $\begin{array}{l}\text { Mainly Spaceloft }{ }^{\circledR} \text { residues after } \\
\text { cutting }\end{array}$ \\
\hline Construction & Transport, lorry $7.5-$ & 274.16 & tkm & A transportation distance from \\
\hline \multirow[t]{5}{*}{ Process } & 16t, EURO5 & & & $\begin{array}{l}\text { AMA COMPOSITES S.R.L. to } \\
\text { the residential block of } \\
\text { buildings of } 1,405 \mathrm{~km} \text {, is } \\
\text { considered. }\end{array}$ \\
\hline & Glue & 8 & $\mathrm{~kg}$ & $\begin{array}{l}\text { Ancillary materials used for the } \\
\text { installation of one Aeropan } \\
\text { panel }\end{array}$ \\
\hline & Mesh & 0.15 & $\mathrm{~kg}$ & \\
\hline & Anchors & 0.10 & $\mathrm{~kg}$ & \\
\hline & $\begin{array}{l}\text { Electricity } \\
\text { consumption }\end{array}$ & 0.05 & $\mathrm{kWh}$ & $\begin{array}{l}\text { Use of an electric drill for } \\
\text { installation }\end{array}$ \\
\hline \multirow[t]{3}{*}{ Use } & $\begin{array}{l}\text { Baseline scenario (w/o } \\
\text { insulation) }\end{array}$ & 85.03 & $\mathrm{kWh} / \mathrm{m}^{2}$ year & $\begin{array}{l}\text { Final energy consumption for } \\
\text { heating during the use phase }\end{array}$ \\
\hline & $\begin{array}{l}\text { Aeropan as internal } \\
\text { insulation }\end{array}$ & 66.32 & $\mathrm{kWh} / \mathrm{m}^{2}$ year & $\begin{array}{l}\text { Final energy consumption for } \\
\text { heating during the use phase }\end{array}$ \\
\hline & $\begin{array}{l}\text { Aeropan as external } \\
\text { insulation }\end{array}$ & 58.87 & $\mathrm{kWh} / \mathrm{m}^{2}$ year & $\begin{array}{l}\text { Final energy consumption for } \\
\text { heating during the use phase }\end{array}$ \\
\hline \multirow[t]{2}{*}{ End-of-life } & $\begin{array}{l}\text { Electricity } \\
\text { consumption }\end{array}$ & 0.5 & $\mathrm{kWh}$ & Deconstruction \\
\hline & Truck lorry of $20-28 \mathrm{t}$ & 0.046 & tkm & Transport to recycling facility \\
\hline
\end{tabular}


Table 6. Environmental implication from cradle to gate approach for $1 \mathrm{~m}^{2}$ of Aeropan with a thickness of $10 \mathrm{~mm}$

\begin{tabular}{|c|c|c|}
\hline Impact category & Unit & Value \\
\hline Global warming potential & $\mathrm{kg} \mathrm{CO}_{2} \mathrm{eq} / \mathrm{m}^{2}$ & $1.61 \mathrm{E}+01$ \\
\hline Ozone depletion potential & $\mathrm{kg}$ CFC $11 \mathrm{eq} / \mathrm{m}^{2}$ & $3.71 \mathrm{E}-06$ \\
\hline Acidification potential & $\mathrm{kg} \mathrm{SO}_{2} \mathrm{eq} / \mathrm{m}^{2}$ & $8.54 \mathrm{E}-02$ \\
\hline Eutrophication potential & $\mathrm{kg}\left(\mathrm{PO}_{4}\right)^{3-} \mathrm{eq} / \mathrm{m}^{2}$ & $1.45 \mathrm{E}-02$ \\
\hline Photochemical ozone creation potential & $\mathrm{kg} \mathrm{C}_{2} \mathrm{H}_{4} \mathrm{eq} / \mathrm{m}^{2}$ & $5.20 \mathrm{E}-03$ \\
\hline Abiotic depletion potential (elements) & $\mathrm{kg} \mathrm{Sb} \mathrm{eq} / \mathrm{m}^{2}$ & $5.22 \mathrm{E}-05$ \\
\hline $\begin{array}{l}\text { Abiotic depletion potential (fossil } \\
\text { fuels) }\end{array}$ & $\mathrm{MJ} / \mathrm{m}^{2}$ & $1.13 \mathrm{E}+02$ \\
\hline Non-renewable primary energy use & $\mathrm{MJ}-\mathrm{eq} / \mathrm{m}^{2}$ & $2.85 \mathrm{E}+02$ \\
\hline Renewable primary energy use & $\mathrm{MJ}-\mathrm{eq} / \mathrm{m}^{2}$ & $1.98 \mathrm{E}+01$ \\
\hline
\end{tabular}


Table 7. Heating and cooling demand of Aeropan's integration internal and external insulation in façade

\begin{tabular}{lcccc}
\hline Scenario & $\begin{array}{c}\text { Cooling } \\
\text { demand } \\
\left(\mathbf{k W h} / \mathbf{m}^{\mathbf{2}} \mathbf{y e a r}\right)\end{array}$ & $\begin{array}{c}\text { Heating } \\
\text { demand } \\
\left(\mathbf{k W h} / \mathbf{m}^{\mathbf{2}} \mathbf{y e a r}\right)\end{array}$ & $\begin{array}{c}\mathbf{U} \text {-value } \\
\left(\mathbf{W} / \mathbf{m}^{\mathbf{2}} \mathbf{K}\right)\end{array}$ & $\begin{array}{c}\text { Aeropan } \\
\text { thickness } \\
(\mathbf{m})\end{array}$ \\
\hline Baseline scenario (w/o insulation) & 32.77 & 78.23 & 1.498 & 0 \\
Aeropan as internal insulation & 35.90 & 61.01 & 0.749 & 0.01 \\
$\begin{array}{l}\text { Aeropan as external } \\
\text { insulation }\end{array}$ & 36.52 & 54.16 & 0.749 & 0.01 \\
\hline
\end{tabular}


Table 8. Impact assessment benefits of the Aeropan's integration as internal and external insulation in façade

\begin{tabular}{|c|c|c|c|}
\hline Impact category & Unit & Internal insulation & $\begin{array}{c}\text { External } \\
\text { insulation }\end{array}$ \\
\hline Global warming potential & $\mathrm{kg} \mathrm{CO} \mathrm{CO}_{2}$ & $1.22 \mathrm{E}+04$ & $1.92 \mathrm{E}+04$ \\
\hline Ozone depletion potential & $\mathrm{kg} \mathrm{CFC} 11 \mathrm{eq}$ & $1.85 \mathrm{E}-03$ & $2.95 \mathrm{E}-03$ \\
\hline Acidification potential & $\mathrm{kg} \mathrm{SO}_{2} \mathrm{eq}$ & $-4.64 \mathrm{E}+00$ & 7.87E-01 \\
\hline Eutrophication potential & $\mathrm{kg}\left(\mathrm{PO}_{4}\right)^{3-} \mathrm{eq}$ & $-1.95 \mathrm{E}+00$ & $-1.09 \mathrm{E}+00$ \\
\hline Photochemical ozone creation potential & $\mathrm{kg} \mathrm{C}_{2} \mathrm{H}_{4}$ eq & $1.04 \mathrm{E}+00$ & $1.79 \mathrm{E}+00$ \\
\hline Abiotic depletion potential (elements) & $\mathrm{kg} \mathrm{Sb} \mathrm{eq}$ & $-3.75 \mathrm{E}-03$ & $-3.75 \mathrm{E}-03$ \\
\hline Abiotic depletion potential (fossil fuels) & MJ & $-8.14 \mathrm{E}+03$ & $-8.13 E+03$ \\
\hline Non-renewable primary energy use & MJ-eq & $-2.05 E+04$ & $-2.05 E+04$ \\
\hline Renewable primary energy use & MJ-eq & $-1.25 \mathrm{E}+03$ & $-9.75 E+02$ \\
\hline
\end{tabular}


Table 9. Comparative scenarios of heating demand $\left(\mathrm{kWh} / \mathrm{m}^{2}\right.$ year) for the hypothetical locations of the case study in Athens (Greece), Madrid (Spain), Bolzano (Italy), Berlin (Germany) and Stockholm (Sweden) (Aeropan as external insulation)

\begin{tabular}{|c|c|c|c|c|c|c|c|c|c|c|}
\hline Scenario & Athens & \% reduction & Madrid & \%reduction & Bolzano & \%reduction & Berlin & \%reduction & Stockholm & \%reduction \\
\hline $\begin{array}{l}\text { Baseline } \\
\text { scenario (w/o } \\
\text { insulation) }\end{array}$ & 44.71 & & 74.03 & & 132.49 & & 165.63 & & 210.6 & \\
\hline $\begin{array}{l}\text { Aeropan as } \\
\text { internal } \\
\text { insulation }\end{array}$ & 34.55 & 22.72 & 59.09 & 20.18 & 108.84 & 17.85 & 132.7 & 19.88 & 170.69 & 18.95 \\
\hline $\begin{array}{l}\text { Aeropan as } \\
\text { external } \\
\text { insulation } \\
\end{array}$ & 30.17 & 32.52 & 52.02 & 29.73 & 100.34 & 24.27 & 122.34 & 26.14 & 157.74 & 25.09 \\
\hline
\end{tabular}


Table 10. Results for the impact assessment benefits of the Aeropan's integration as internal and external insulation in façade in the hypothetical locations

\begin{tabular}{|c|c|c|c|c|c|c|c|c|c|c|c|}
\hline \multirow[b]{2}{*}{$\begin{array}{l}\text { Impact } \\
\text { category }\end{array}$} & \multirow[b]{2}{*}{ Unit } & \multicolumn{2}{|c|}{ Athens } & \multicolumn{2}{|c|}{ Madrid } & \multicolumn{2}{|c|}{ Bolzano } & \multicolumn{2}{|c|}{ Berlin } & \multicolumn{2}{|c|}{ Stockholm } \\
\hline & & $\begin{array}{l}\text { Internal } \\
\text { insulation }\end{array}$ & $\begin{array}{l}\text { External } \\
\text { insulation }\end{array}$ & $\begin{array}{l}\text { Internal } \\
\text { insulation }\end{array}$ & $\begin{array}{l}\text { External } \\
\text { insulation }\end{array}$ & $\begin{array}{l}\text { Internal } \\
\text { insulation }\end{array}$ & $\begin{array}{l}\text { External } \\
\text { insulation }\end{array}$ & $\begin{array}{l}\text { Internal } \\
\text { insulation }\end{array}$ & $\begin{array}{c}\text { External } \\
\text { insulation }\end{array}$ & $\begin{array}{l}\text { Internal } \\
\text { insulation }\end{array}$ & $\begin{array}{l}\text { External } \\
\text { insulation }\end{array}$ \\
\hline $\begin{array}{l}\text { Global } \\
\text { warming } \\
\text { potential }\end{array}$ & $\begin{array}{l}\mathrm{kg} \mathrm{CO}_{2} \\
\mathrm{eq}\end{array}$ & $4.95 \mathrm{E}+03$ & $9.44 \mathrm{E}+03$ & $9.85 \mathrm{E}+03$ & $1.71 \mathrm{E}+04$ & $1.88 \mathrm{E}+04$ & $2.75 \mathrm{E}+04$ & $2.83 \mathrm{E}+04$ & $3.89 \mathrm{E}+04$ & $3.54 \mathrm{E}+04$ & $4.87 \mathrm{E}+04$ \\
\hline $\begin{array}{l}\text { Ozone } \\
\text { depletion } \\
\text { potential }\end{array}$ & $\begin{array}{l}\mathrm{kg} \mathrm{CFC} \\
11 \mathrm{eq}\end{array}$ & 7.22E-04 & $1.42 \mathrm{E}-03$ & $1.49 \mathrm{E}-03$ & $2.62 \mathrm{E}-03$ & $2.88 \mathrm{E}-03$ & $4.24 \mathrm{E}-03$ & $4.36 \mathrm{E}-03$ & $6.02 \mathrm{E}-03$ & $5.48 \mathrm{E}-03$ & $7.55 \mathrm{E}-03$ \\
\hline $\begin{array}{l}\text { Acidification } \\
\text { potential }\end{array}$ & $\begin{array}{ll}\mathrm{kg} & \mathrm{SO}_{2} \\
\mathrm{eq} & \end{array}$ & $-1.02 \mathrm{E}+01$ & $-6.76 \mathrm{E}+00$ & $-6.44 \mathrm{E}+00$ & $-8.45 \mathrm{E}-01$ & 4.54E-01 & $7.19 \mathrm{E}+00$ & $7.80 \mathrm{E}+00$ & $1.60 \mathrm{E}+01$ & $1.33 \mathrm{E}+01$ & $2.36 \mathrm{E}+01$ \\
\hline $\begin{array}{l}\text { Eutrophication } \\
\text { potential }\end{array}$ & $\begin{array}{l}\mathrm{kg} \\
\left(\mathrm{PO}_{4}\right)^{3-} \\
\mathrm{eq}\end{array}$ & $-2.84 \mathrm{E}+00$ & $-2.29 \mathrm{E}+00$ & $-2.23 \mathrm{E}+00$ & $-1.34 \mathrm{E}+00$ & $-1.14 \mathrm{E}+00$ & $-6.76 \mathrm{E}-02$ & $3.06 \mathrm{E}-02$ & $1.34 \mathrm{E}+00$ & $9.10 \mathrm{E}-01$ & $2.54 \mathrm{E}+00$ \\
\hline $\begin{array}{l}\text { Photochemical } \\
\text { ozone creation } \\
\text { potential }\end{array}$ & $\begin{array}{l}\mathrm{kg} \\
\mathrm{C}_{2} \mathrm{H}_{4} \\
\mathrm{eq}\end{array}$ & $2.75 \mathrm{E}-01$ & $7.53 \mathrm{E}-01$ & $7.96 \mathrm{E}-01$ & $1.57 \mathrm{E}+00$ & $1.75 \mathrm{E}+00$ & $2.67 \mathrm{E}+00$ & $2.76 \mathrm{E}+00$ & $3.89 \mathrm{E}+00$ & $3.52 \mathrm{E}+00$ & $4.93 \mathrm{E}+00$ \\
\hline $\begin{array}{l}\text { Abiotic } \\
\text { depletion } \\
\text { potential } \\
\text { (elements) }\end{array}$ & $\begin{array}{ll}\mathrm{kg} & \mathrm{Sb} \\
\mathrm{eq} & \end{array}$ & $-3.75 \mathrm{E}-03$ & $-3.75 \mathrm{E}-03$ & $-3.75 \mathrm{E}-03$ & $-3.75 \mathrm{E}-03$ & $-3.75 \mathrm{E}-03$ & $-3.75 \mathrm{E}-03$ & $-3.75 \mathrm{E}-03$ & $-3.75 \mathrm{E}-03$ & $-3.75 \mathrm{E}-03$ & $-3.75 \mathrm{E}-03$ \\
\hline $\begin{array}{l}\text { Abiotic } \\
\text { depletion } \\
\text { potential } \\
\text { (fossil fuels) }\end{array}$ & MJ & $-8.15 E+03$ & $-8.15 E+03$ & $-8.15 E+03$ & $-8.14 \mathrm{E}+03$ & $-8.14 \mathrm{E}+03$ & $-8.12 \mathrm{E}+03$ & $-8.12 \mathrm{E}+03$ & $-8.11 \mathrm{E}+03$ & $-8.12 \mathrm{E}+03$ & $-8.10 \mathrm{E}+03$ \\
\hline $\begin{array}{l}\text { Non- } \\
\text { renewable } \\
\text { primary } \\
\text { energy use }\end{array}$ & MJ-eq & $-2.05 \mathrm{E}+04$ & $-2.05 \mathrm{E}+04$ & $-2.05 \mathrm{E}+04$ & $-2.05 \mathrm{E}+04$ & $-2.05 \mathrm{E}+04$ & $-2.05 \mathrm{E}+04$ & $-2.05 \mathrm{E}+04$ & $-2.04 \mathrm{E}+04$ & $-2.04 \mathrm{E}+04$ & $-2.04 \mathrm{E}+04$ \\
\hline $\begin{array}{l}\text { Renewable } \\
\text { primary } \\
\text { energy use }\end{array}$ & MJ-eq & $-1.54 \mathrm{E}+03$ & $-1.36 \mathrm{E}+03$ & $-1.35 \mathrm{E}+03$ & $-1.06 \mathrm{E}+03$ & $-9.92 \mathrm{E}+02$ & $-6.45 \mathrm{E}+02$ & $-6.13 \mathrm{E}+02$ & $-1.91 \mathrm{E}+02$ & $-3.29 \mathrm{E}+02$ & $2.00 \mathrm{E}+02$ \\
\hline
\end{tabular}


Table 11. Comparative scenarios of heating demand $\left(\mathrm{kWh} / \mathrm{m}^{2}\right.$ year) for the hypothetical locations considering different U-value achieved by Aeropan's integration as external insulation

\begin{tabular}{ccrrrrr}
\hline $\begin{array}{c}\text { Thickness } \\
(\mathbf{m})\end{array}$ & $\begin{array}{l}\text { U- Value } \\
\left(\mathbf{W} / \mathbf{m}^{2} \mathbf{K}\right)\end{array}$ & \multicolumn{1}{c}{ Athens } & \multicolumn{1}{c}{ Madrid } & \multicolumn{1}{c}{ Bolzano } & Berlin & Stockholm \\
\hline 0.00 & 1.49 & 44.71 & 74.03 & 132.49 & 165.63 & 210.60 \\
0.01 & 0.75 & 30.17 & 52.02 & 100.34 & 122.34 & 157.74 \\
0.02 & 0.50 & 26.61 & 46.74 & 91.93 & 111.54 & 144.11 \\
0.03 & 0.38 & 24.77 & 44.01 & 87.32 & 106.16 & 137.15 \\
0.04 & 0.30 & 23.66 & 42.33 & 84.58 & 102.98 & 132.97 \\
0.05 & 0.25 & 22.91 & 41.21 & 82.75 & 100.89 & 130.19 \\
0.06 & 0.21 & 22.38 & 40.42 & 81.45 & 99.43 & 128.25 \\
0.07 & 0.19 & 21.98 & 39.83 & 80.49 & 98.39 & 126.82 \\
0.08 & 0.17 & 21.67 & 39.39 & 79.78 & 97.6 & 125.75 \\
0.09 & 0.15 & 21.45 & 39.03 & 79.23 & 97.00 & 124.92 \\
0.10 & 0.14 & 21.22 & 38.75 & 78.79 & 96.54 & 124.27 \\
\hline
\end{tabular}


Table 12. Comparative analysis of the impact assessment benefits of the Aeropan's integration as internal and external insulation in the Madrid case considering natural gas, electricity and diesel as alternative fuels

\begin{tabular}{|c|c|c|c|c|c|c|c|}
\hline \multirow[b]{2}{*}{ Impact category } & \multirow[b]{2}{*}{ Unit } & \multicolumn{2}{|c|}{ Natural gas } & \multicolumn{2}{|c|}{ Electricity } & \multicolumn{2}{|c|}{ Diesel } \\
\hline & & $\begin{array}{c}\text { Internal } \\
\text { insulation }\end{array}$ & $\begin{array}{r}\text { External } \\
\text { insulation }\end{array}$ & $\begin{array}{c}\text { Internal } \\
\text { insulation }\end{array}$ & $\begin{array}{c}\text { External } \\
\text { insulation }\end{array}$ & $\begin{array}{c}\text { Internal } \\
\text { insulation }\end{array}$ & $\begin{array}{c}\text { External } \\
\text { insulation }\end{array}$ \\
\hline $\begin{array}{l}\text { Global warming } \\
\text { potential }\end{array}$ & $\mathrm{kg} \mathrm{CO}_{2} \mathrm{eq}$ & $9.85 \mathrm{E}+03$ & $1.71 \mathrm{E}+04$ & $2.67 \mathrm{E}+04$ & $4.18 \mathrm{E}+04$ & $1.31 \mathrm{E}+04$ & $2.18 \mathrm{E}+04$ \\
\hline $\begin{array}{l}\text { Ozone depletion } \\
\text { potential }\end{array}$ & $\mathrm{kg} \mathrm{CFC11} \mathrm{eq}$ & $1.49 \mathrm{E}-03$ & $2.62 \mathrm{E}-03$ & $9.81 \mathrm{E}-04$ & $1.87 \mathrm{E}-03$ & $1.83 \mathrm{E}-03$ & $3.13 \mathrm{E}-03$ \\
\hline $\begin{array}{l}\text { Acidification } \\
\text { potential }\end{array}$ & $\mathrm{kg} \mathrm{SO}_{2} \mathrm{eq}$ & $-6.44 \mathrm{E}+00$ & $-8.45 \mathrm{E}-01$ & $2.85 \mathrm{E}+02$ & $4.28 \mathrm{E}+02$ & $2.01 \mathrm{E}+01$ & $3.82 \mathrm{E}+01$ \\
\hline $\begin{array}{l}\text { Eutrophication } \\
\text { potential }\end{array}$ & $\mathrm{kg}\left(\mathrm{PO}_{4}\right)^{3-} \mathrm{eq}$ & $-2.23 \mathrm{E}+00$ & $-1.34 \mathrm{E}+00$ & $5.24 \mathrm{E}+01$ & $7.91 \mathrm{E}+01$ & $1.90 \mathrm{E}-01$ & $2.23 \mathrm{E}+00$ \\
\hline $\begin{array}{l}\text { Photochemical } \\
\text { ozone creation } \\
\text { potential }\end{array}$ & $\mathrm{kg} \mathrm{C}_{2} \mathrm{H}_{4}$ eq & 7.96E-01 & $1.57 \mathrm{E}+00$ & $1.03 \mathrm{E}+01$ & $1.56 \mathrm{E}+01$ & $1.18 \mathrm{E}+00$ & $2.13 \mathrm{E}+00$ \\
\hline $\begin{array}{l}\text { Abiotic depletion } \\
\text { potential } \\
\text { (elements) }\end{array}$ & $\mathrm{kg} \mathrm{Sb}$ eq & $-3.75 \mathrm{E}-03$ & $-3.75 \mathrm{E}-03$ & $-3.75 \mathrm{E}-03$ & $-3.75 \mathrm{E}-03$ & $-3.75 \mathrm{E}-03$ & $-3.75 \mathrm{E}-03$ \\
\hline $\begin{array}{l}\text { Abiotic depletion } \\
\text { potential (fossil } \\
\text { fuels) }\end{array}$ & MJ & $-8.15 \mathrm{E}+03$ & $-8.14 \mathrm{E}+03$ & $-4.76 \mathrm{E}+03$ & $-3.16 \mathrm{E}+03$ & $-8.14 \mathrm{E}+03$ & $-8.13 \mathrm{E}+03$ \\
\hline $\begin{array}{l}\text { Non-renewable } \\
\text { primary energy } \\
\text { use }\end{array}$ & MJ-eq & $-2.05 \mathrm{E}+04$ & $-2.05 \mathrm{E}+04$ & $-1.66 \mathrm{E}+04$ & $-1.48 \mathrm{E}+04$ & $-2.05 \mathrm{E}+04$ & $-2.05 \mathrm{E}+04$ \\
\hline $\begin{array}{l}\text { Renewable } \\
\text { primary energy } \\
\text { use }\end{array}$ & MJ-eq & $-1.35 \mathrm{E}+03$ & $-1.06 \mathrm{E}+03$ & $6.17 \mathrm{E}+04$ & $9.18 \mathrm{E}+04$ & $-4.50 \mathrm{E}+02$ & $2.63 \mathrm{E}+02$ \\
\hline
\end{tabular}


Table 13. Main characteristics of the conventional insulation materials analysed

\begin{tabular}{|c|c|c|c|c|}
\hline Layer & $\begin{array}{c}\text { Conductivity } \\
(\mathrm{W} / \mathrm{mK})\end{array}$ & $\begin{array}{c}\text { Specific heat } \\
(\mathrm{J} / \mathrm{kgK})\end{array}$ & $\begin{array}{l}\text { Density } \\
\left(\mathrm{kg} / \mathrm{m}^{3}\right)\end{array}$ & Source \\
\hline XPS with $\mathrm{CO}_{2}$ & 0.034 & 1,000 & 37.5 & $\begin{array}{l}\text { (Eduardo Torroja } \\
\text { Construction Sciences } \\
\text { Institute with the } \\
\text { collaboration of CEPCO } \\
\text { and AICIA, 2010) }\end{array}$ \\
\hline EPS & 0.046 & 1,000 & 30.0 & $\begin{array}{l}\text { (Eduardo Torroja } \\
\text { Construction Sciences } \\
\text { Institute with the } \\
\text { collaboration of CEPCO } \\
\text { and AICIA, 2010) }\end{array}$ \\
\hline Mineral wool & 0.050 & 1,000 & 40.0 & $\begin{array}{l}\text { (Eduardo Torroja } \\
\text { Construction Sciences } \\
\text { Institute with the } \\
\text { collaboration of CEPCO } \\
\text { and AICIA, 2010) }\end{array}$ \\
\hline
\end{tabular}


Table 14. U-value limits set by the different national regulations

\begin{tabular}{lll}
\hline Country & Regulation & U-value limit \\
\hline Greece & $\begin{array}{l}\text { Hellenic ministry of environment, energy and Climatic change - } \\
\text { YPEKA, 2010 }\end{array}$ & $\begin{array}{l}0.6 \mathrm{~W} / \mathrm{m}^{2} \mathrm{~K} \\
\text { (A zone) }\end{array}$ \\
Spain & CTE DB-HE, 2013 & $0.66 \mathrm{~W} / \mathrm{m}^{2} \mathrm{~K}$ \\
Italy & Parlamento della Repubblica Italiana, 2009 & (D) zone) \\
& & $0.34 \mathrm{~W} / \mathrm{m}^{2} \mathrm{~K}$ \\
Germany & DIN 4108-2:2003-2007 & zone)
\end{tabular}

